NIST Technical Note 1894

\title{
Effects of Wind Speed and Angle on Fire Spread along Privacy Fences
}

\author{
Erik L. Johnsson \\ Alexander Maranghides
}

This publication is available free of charge from:

http://dx.doi.org/10.6028/NIST.TN.1894

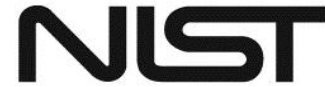

National Institute of Standards and Technology

U.S. Department of Commerce 



\title{
Effects of Wind Speed and Angle on Fire Spread along Privacy Fences
}

\author{
Erik L. Johnsson \\ Alexander Maranghides \\ Engineering Laboratory
}

National Institute of Standards and Technology

This publication is available free of charge from:

http://dx.doi.org/10.6028/NIST.TN.1894

July 2016

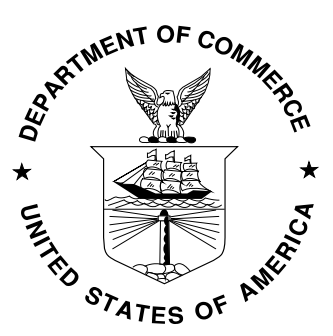

U.S. Department of Commerce

Penny Pritzker, Secretary

National Institute of Standards and Technology

Willie May, Under Secretary of Commerce for Standards and Technology and Director 
Certain commercial entities, equipment, or materials may be identified in this document in order to describe an experimental procedure or concept adequately. Such identification is not intended to imply recommendation or endorsement by the National Institute of Standards and Technology, nor is it intended to imply that the entities, materials, or equipment are necessarily the best available for the purpose.

National Institute of Standards and Technology Technical Note 1894

Natl. Inst. Stand. Technol. Tech. Note 1894, 27 pages (July 2016) CODEN: NTNOEF

This publication is available free of charge from: http://dx.doi.org/10.6028/NIST.TN.1894 


\begin{abstract}
A series of experiments was conducted to examine fire spread along fences subjected to wind at various speeds and angles. Specifically, sections of western redcedar, California redwood, or vinyl privacy fences were ignited with a burner. Wind fields of $9 \mathrm{~m} / \mathrm{s}, 13.5 \mathrm{~m} / \mathrm{s}$, or $18 \mathrm{~m} / \mathrm{s}$ aligned with, perpendicular to, or at a $45^{\circ}$ angle to the fences were applied during the experiments. To simulate fine fuels typically present in real installations, dried shredded hardwood mulch beds were placed under most of the fence sections. Also, some fence sections were coated with fence preservative to assess its effect on fire spread. Pans of mulch were downwind targets for firebrands produced by the burning fence and mulch bed. At all wind speeds tested, a mulch bed was required for flames to spread. Fastest flame spread was achieved with the fence aligned with the wind field. During most experiments, the burning mulch and fences produced firebrands which ignited spot fires in the mulch targets. These experiments demonstrated that ignited wood fence structures can be rapid conduits for fire along them and potentially spread fire to attached or adjacent structures. Additionally, it was found that burning fences can produce spot fires from their own firebrand generation. This study of fence fire spread is part of a series designed to better inform standards and codes regarding placement of landscape features around homes at risk of exposure to wildland-urban interface fires.
\end{abstract}

\title{
KEYWORDS
}

WUI fires; firebrands; embers; wildland urban interface fires; fence fires; structural ignition; structural firebrands; fire spread 


\section{TABLE OF CONTENTS}

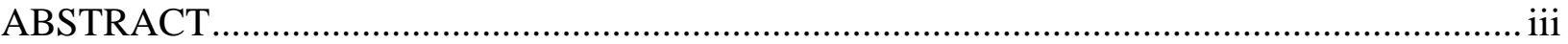

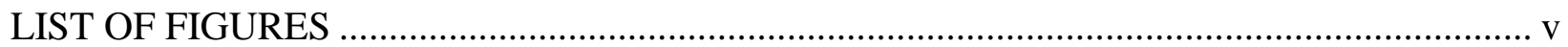

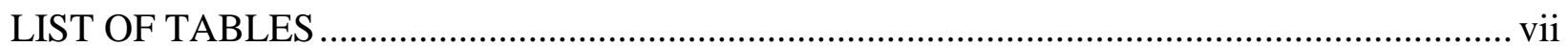

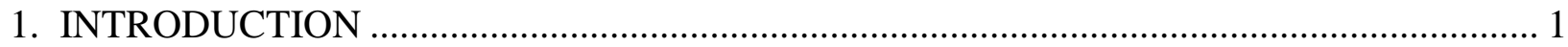

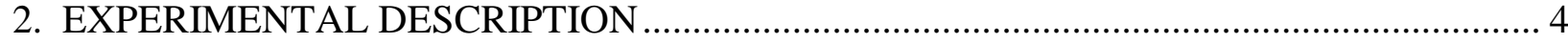

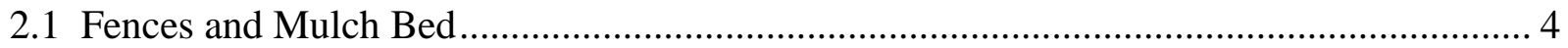

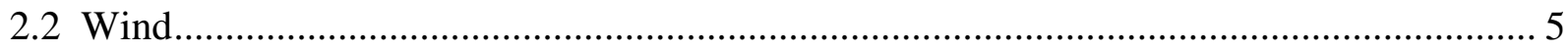

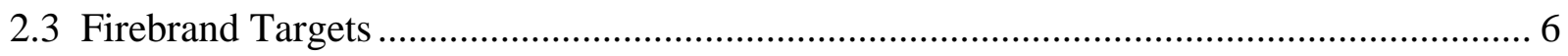

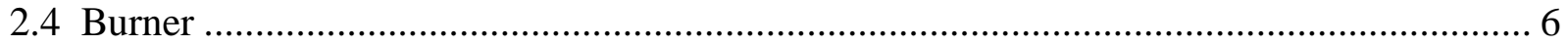

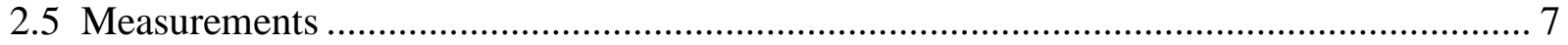

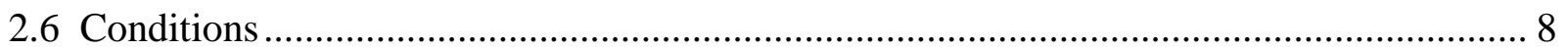

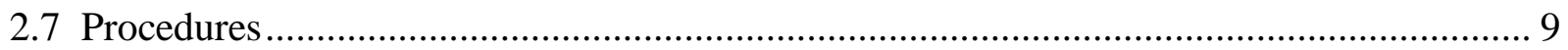

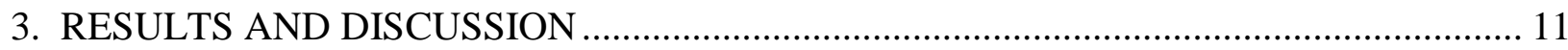

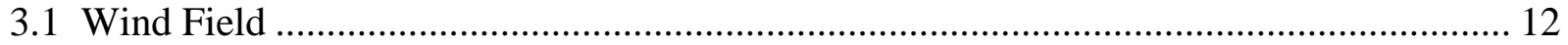

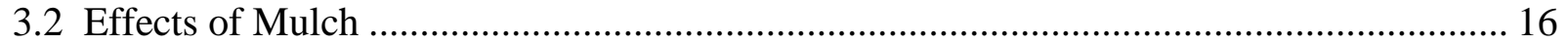

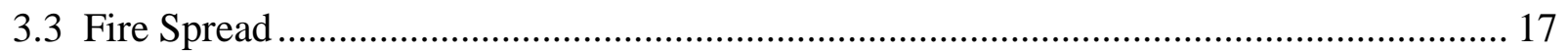

3.4 Effects of Other Variables .............................................................................. 19

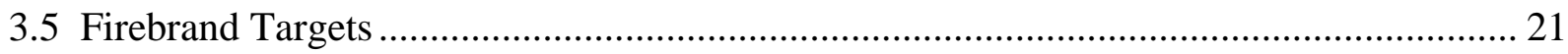

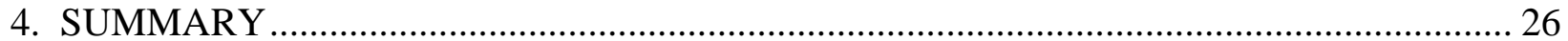

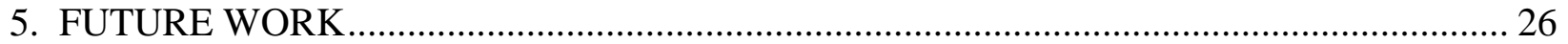

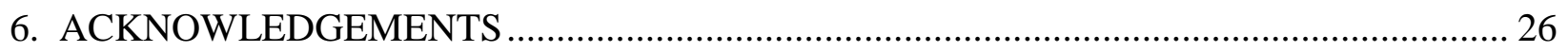

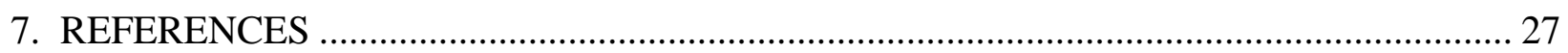




\section{LIST OF FIGURES}

Figure 1 Picture of an ignited wood fencing assembly in Colorado, 2012; Courtesy of Colorado Springs Fire Department. .............................................................................. 2

Figure 2 Cartoon of the major components of the wind-driven fence fire spread experiments. .... 4

Figure 3 Photograph of the overall experimental set-up for the wind-driven fence fire spread experiments showing the airboat, angled flow straightener, corridor, and fence oriented at $45^{\circ}$

\section{6}

Figure 4 Photographs of a pair of firebrand targets after Test 7 (cedar at $45^{\circ}, 13.5 \mathrm{~m} / \mathrm{s}$ ). One pan is filled with about $2 \mathrm{~cm}$ of mulch (left) and the other contains about $4 \mathrm{~mm}$ of water (right). These were placed in $3.05 \mathrm{~m}$ intervals downwind of the trailing edge of the

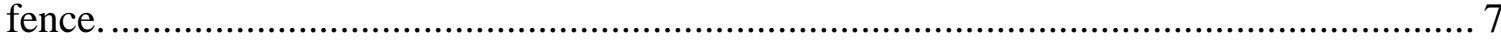

Figure 5 A diagram of the bi-directional probe array used to measure the velocity field. ............ 8 Figure 6 A top view schematic of the experimental setup showing the relative positions of the fence, targets, and video cameras for the three fence orientation angles....................... 11

Figure 7 A plot of 4 min of velocity versus time data from the middle height $(0.91 \mathrm{~m}$ from ground) bi-directional probe on the centerline for Test 9 (cedar, $0^{\circ}, 13.5 \mathrm{~m} / \mathrm{s}$ ) showing the level of velocity fluctuations measured.

Figure 8 A plot of height versus velocity for the tests with complete vertical velocity data for the nominal wind speed of $9 \mathrm{~m} / \mathrm{s}$. The points represent the mean velocities during the steady wind period. Standard errors for the average velocities ranged from $0.02 \mathrm{~m} / \mathrm{s}$ to $0.06 \mathrm{~m} / \mathrm{s}$. Smooth curves were fit through the points to facilitate visualization of the profile......... 13

Figure 9 A plot of height versus velocity for the tests with complete vertical profile velocity data for the nominal wind speed of $13.5 \mathrm{~m} / \mathrm{s}$. The points represent the mean velocities during the steady wind period. Standard errors for the average velocities ranged from less than $0.01 \mathrm{~m} / \mathrm{s}$ to $0.17 \mathrm{~m} / \mathrm{s}$. Smooth curves were fit through the points to facilitate visualization of the profile.

Figure 10 A plot of velocity versus distance from the centerline for the tests with complete horizontal profile velocity data for the nominal wind speed of $9 \mathrm{~m} / \mathrm{s}$. The points represent the mean velocities during the steady wind period. Standard errors for the average velocities ranged from $0.02 \mathrm{~m} / \mathrm{s}$ to $0.06 \mathrm{~m} / \mathrm{s}$. Lines were fit through the points to facilitate visualization of the profile.

Figure 11 A plot of velocity versus distance from the centerline for the tests with complete horizontal profile velocity data for the nominal wind speed of $13.5 \mathrm{~m} / \mathrm{s}$. The points represent the mean velocities during the steady wind period. Standard errors for the average velocities ranged from less than $0.01 \mathrm{~m} / \mathrm{s}$ to $0.21 \mathrm{~m} / \mathrm{s}$. Lines were fit through the points to facilitate visualization of the profile.

Figure 12 Photographs of Test 15 (cedar at $0^{\circ}, 13.5 \mathrm{~m} / \mathrm{s}$ ) showing progression of the fire: ignition (UL), initial wind-blown fire (UR), spread to half of the fence (BL), and spread to the full fence (BR). Wind direction was left to right. 20

Figure 13 Photograph from Test 13 (preservative-coated cedar at $0^{\circ}, 13.5 \mathrm{~m} / \mathrm{s}$ ) showing flames attached to several fence boards and a significant amount of material burned away from the board ends. Wind direction was left to right.

Figure 14 Photograph from Test 12 (preservative-coated redwood at $0^{\circ}, 13.5 \mathrm{~m} / \mathrm{s}$ ) showing substantial burning of the lower $2 / 3$ of the structure side of the fence after the fire progressed (from right to left) to the end. 
Figure 15 Photographs from Test 9 (cedar at $0^{\circ}, 13.5 \mathrm{~m} / \mathrm{s}$ ) showing three perspectives on the first $(3.05 \mathrm{~m})$ target pan with burning mulch and airborne firebrands. ................................ 24

Figure $16 \mathrm{~A}$ photograph of a fence-generated firebrand in the first ( $3.05 \mathrm{~m}$ from fence) water pan surrounded by smaller mulch-generated firebrands produced during Test 12 (preservative-coated redwood at $0^{\circ}, 13.5 \mathrm{~m} / \mathrm{s}$ ). Additional photographs provide size reference for the firebrand.

Figure 17 A photograph of a weathered and cracked railroad tie type of timber located over $18 \mathrm{~m}$ from the fence (upper left). During Test 10 (cedar at $0^{\circ}, 18 \mathrm{~m} / \mathrm{s}$ ), the timber was ignited in at least two locations where firebrands accumulated in cracks. The other photograph (bottom right) shows firebrands flying near the other end of the timber. 


\section{LIST OF TABLES}

Table 1 Parameters Explored. The parameters and number of conditions explored for each are listed.

Table 2 Test Matrix. Experimental conditions are listed for each experiment........................... 10

Table 3 Fire Spread Results. Times for fire spread for those experiments which burned from the ignition point to the end of the fence under one set of conditions.............................. 18

Table 4 Firebrand Target Results. Incidence of mulch ignition in targets spaced $3.05 \mathrm{~m}, 6.1 \mathrm{~m}$,

$9.14 \mathrm{~m}$, and $12.19 \mathrm{~m}$ downwind from the trailing edge of the fence. 23 


\section{INTRODUCTION}

During investigations following Wildland-Urban Interface (WUI) fires, fences along with adjoining structures have been discovered burned, and instances of fires spreading to structures along fences have been observed in WUI fire events in California - Witch Creek [1] and Colorado - Waldo Canyon [2]. The role of fences and other exterior landscape features as channels of fire spread to structures is of interest to the WUI-fire research community. Better understanding would enable efforts to design new or harden existing structures and exterior features to resist ignition and fire spread. The experimental series described here focused on fences. Additional studies addressing woodpiles, landscape timbers, and vegetation are planned.

WUI fires have been destroying communities around the United States and are getting worse in frequency and increased damage costs as more communities are built on the edge of wildlands. [3, 4] Recent notable examples were the 2011 Texas Bastrop Complex Fire [5] and the 2012 Colorado Waldo Canyon Fire [2].

Fire research regarding structure fires has traditionally focused on interior ignitions from a variety of sources such as electrical problems, heating sources, cigarettes, and unattended cooking, but WUI fires ignite the exteriors of structures through firebrands, flame radiation, or flame impingement or sometimes by firebrands penetrating into the interior through vulnerable openings in the building envelope. The complexities of these interactions between exterior exposure (both from vegetative fires and burning structures) and the built environment have barely begun to be explored. This is confounded by the large number of potential fire and firebrand exposure scenarios and the wide variety of exterior construction materials and assemblies. Research is urgently needed to better understand WUI-fire-structure interactions and to technically support changes to building and community designs and codes to mitigate the increasing losses from the growing number of WUI fire incidents. Understanding WUI fire ignition of structural components in order to be able to harden the structures against WUI fire ignition and fire spread has become a recent focus of research conducted at the National Institute of Standards and Technology (NIST). With the development of a firebrand generator to simulate wind-blown firebrand showers [6], recent experiments have been conducted with the goal of quantifying the vulnerabilities of structures to firebrand ignition. The vulnerabilities investigated thus far are building vents [7], tile roofs [8], siding and eaves [9], and decks [10]

Post-fire studies conducted by NIST after the 2012 Waldo Canyon Fire in Colorado determined that wood fences were susceptible to ignition from WUI fire firebrands and that the fire spread along fences could act as conduits for ignition of adjacent structures. The Waldo Fire Case Study [2], conducted by NIST in conjunction with the U. S. Forest Service and the Joint Fire Science Program, identified 73 separate fences on fire in the Mountain Shadows community. There were 670 parcels in the study domain although field data were not collected on the total number of fences within the domain or on the construction materials of the burned fences. Figure 1 is photograph of an ignited wood fencing assembly in Colorado. While there was recent experimental verification of the ignitability of fences by wind-blown firebrands [11], there have not been any studies of the fire spread behavior once a fence is ignited. 


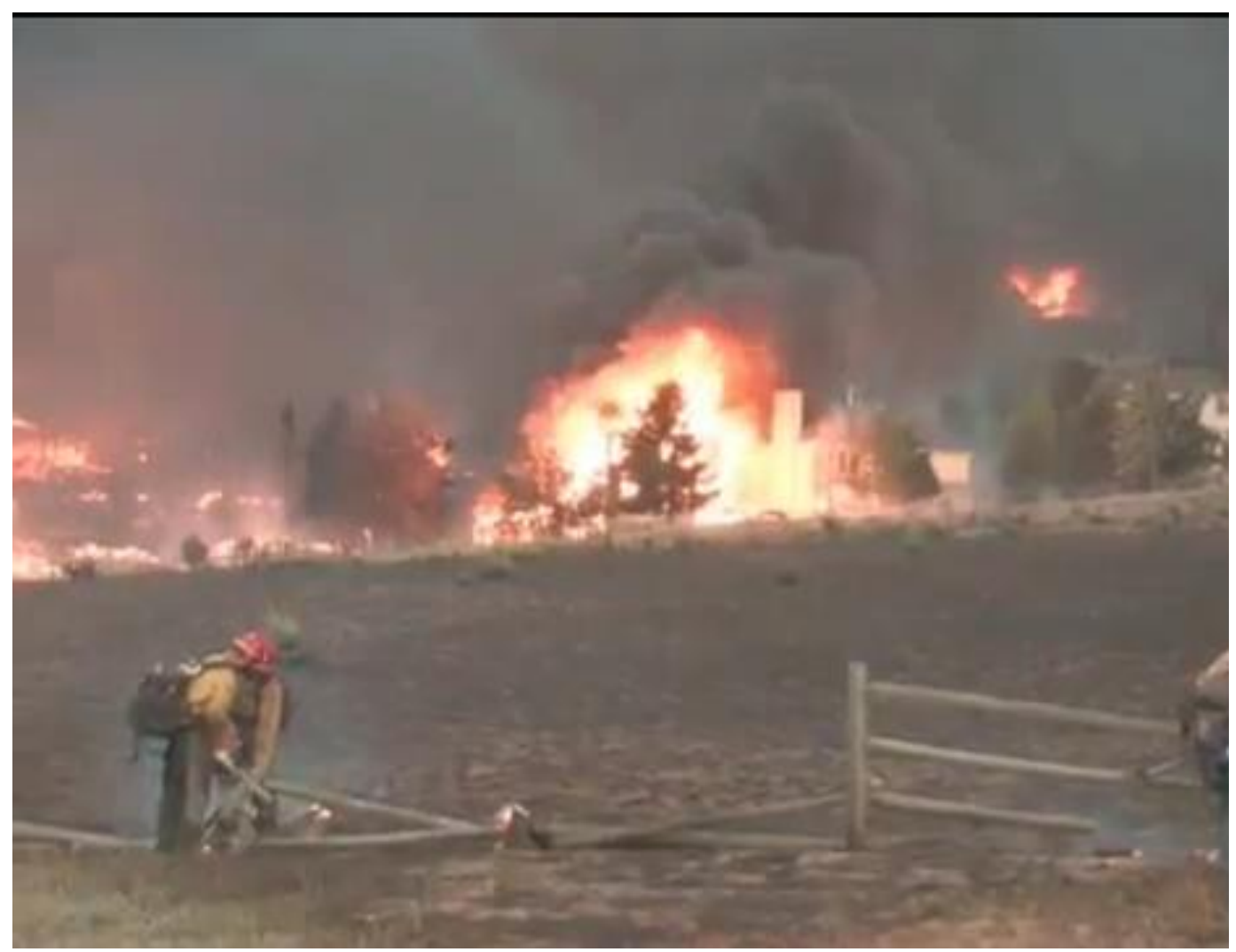

Figure 1 Picture of an ignited wood fencing assembly in Colorado, 2012; Courtesy of Colorado Springs Fire Department.

There have been few articles in the literature relating ignition of wood fencing assemblies to WUI fire exposures. One study in Australia [12] examined the ignition of fences of various types and materials by ignited leaf litters, but the experiments were not conducted under windy conditions, and the focus was only on ignition and not fire spread. A recent study in Russia [13] examined ignition of fences and wooden shields by fires propagating along various ground vegetation, but the wind speeds were low, and again, ignition was the main focus.

In order to examine the fire spread behavior of ignited wood fences, outdoor experiments were conducted by NIST. A series of experiments was conducted to examine the spread of fire along wood fences subjected to wind at various angles. Specifically, sections of western redcedar, California redwood, or vinyl privacy fences were ignited with a burner near one end, while wind fields of various speeds were applied with the fence at different angles to the wind.

The experiments were conducted at the Montgomery County Fire and Rescue Training Academy (MCFRTA) grounds in Rockville, MD. An airboat operated by the Sandy Spring Volunteer Fire Department (SSVFD) provided a wind source. To simulate fine fuels typically present in many real installations, dried shredded hardwood mulch beds were placed under most of the fence sections to observe how this affected fire spread. Also, some fence sections were coated with fence preservative to see if it had an effect on fire spread. Pans of mulch were placed downwind as targets for firebrands produced by the burning fence and/or mulch bed. 
The overall goal of the experiments was to provide a better understanding of the phenomenon of fire spread along fences and to determine the severity of the hazard. The main objectives of the experiments were:

- $\quad$ To observe the burning behavior of wind-driven privacy-fence fires;

- $\quad$ To understand the rate of fire spread along privacy fences as related to wind speed and wind direction;

- To determine the impact of fence material type, preservative, and ground cover on the fire spread rate;

- To determine whether the fence-borne fire poses a potential ignition danger to any attached or adjacent structure;

- $\quad$ To ascertain whether a burning fence installation produces significant firebrands capable of igniting downwind combustibles; and

- $\quad$ To determine the feasibility of utilizing an airboat for a reproducible, controlled, and realistic wind source for outdoor wind-driven fire experiments.

It is also anticipated that this and planned follow-up work on fire spread to structures via fences and other home landscape features will contribute technical knowledge for improved codes and standards for exterior, peripheral structures and efforts to address the WUI fire problem by hardening structures. $[14,15]$ Additional research will also be needed to explore methods of hardening such as separation distances, non-combustible interfaces, coatings, less vulnerable design options, etc. 


\section{EXPERIMENTAL DESCRIPTION}

The basic experimental set-up consisted of an airboat, flow straightener, walls, fence, mulch pan, burner, firebrand targets, and measurement equipment. Figure 2 is a cartoon of the major components of the experiment. The experiments were located at the MCFRTA which is used for a variety of indoor and outdoor fire training so the set-up had to be confined to a relatively small area away from other facilities and combustibles. Testing was also, in some cases, curtailed due to cold, likely chances of rain, and ambient winds over $7 \mathrm{~m} / \mathrm{s}(\approx 15 \mathrm{mph})$.

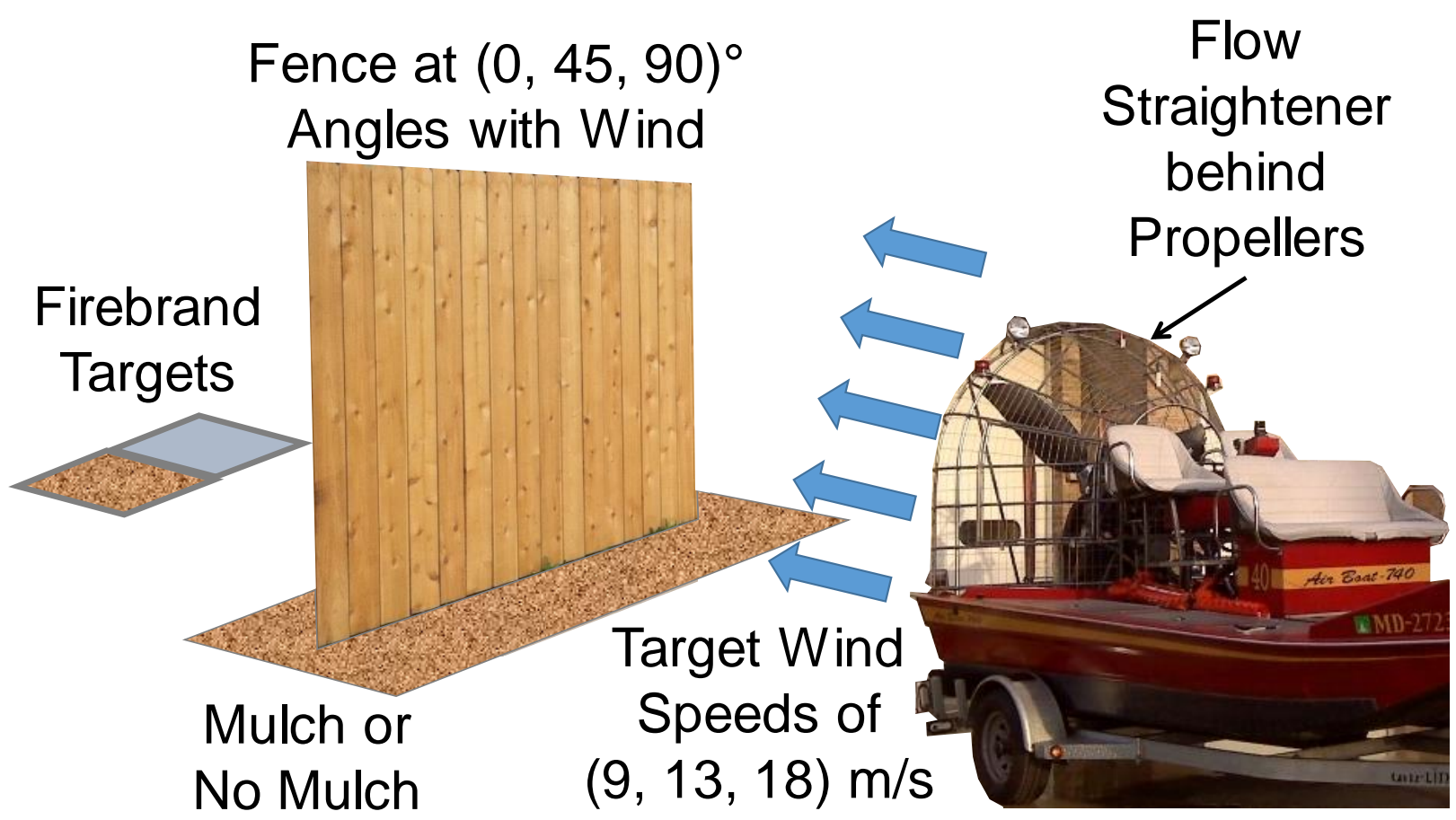

Figure 2 Cartoon of the major components of the wind-driven fence fire spread experiments.

\subsection{Fences and Mulch Bed}

An informal survey of southern California and northern Texas fence companies found privacy fences are the most common type although a variety of top styles are used (cap, dog-ear, lattice, etc.). The simplest style privacy fence (plain flat top) was selected for this initial series of experiments. Western redcedar, California redwood, and vinyl were the most common materials used in the survey and were thus chosen for this study. Also, $19 \mathrm{~mm}$ x $140 \mathrm{~mm}$ (nominal 1 in $\mathrm{x}$ 6 in) boards were chosen as they seemed to be more common than $19 \mathrm{~mm}$ x $89 \mathrm{~mm}$ (nominal 1 in $\mathrm{x} 4$ in) boards. The sections of fence were manufactured locally by a fence construction company to maintain commercial standards and consistency. The dimensions of the fence

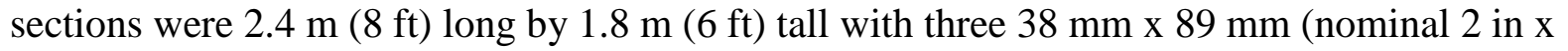
$4 \mathrm{in}$ ) horizontal stringers or rails (pressure treated pine). The board dimensions were $14 \mathrm{~cm}$ (5.5 in) wide and $19 \mathrm{~mm}$ (3/4 in) thick. Spacing between the vertical boards varied from $0.5 \mathrm{~mm}$ (0.02 in) to $3 \mathrm{~mm}(0.12 \mathrm{in})$ and averaged $1.5 \mathrm{~mm}(0.06 \mathrm{in})$. The wood of the fences was stored in 
a dry, but unconditioned space near the experiments. Moisture content of the wood was estimated at $12.5 \% \pm 1.0 \%$ [16] which produced realistic conditions for fire spread rather than enhanced conditions which would result from using dried wood.

Three configurations with respect to the wind direction were tested: $0^{\circ}$ (parallel), $45^{\circ}$, and $90^{\circ}$ (perpendicular). For most of the $45^{\circ}$ and $90^{\circ}$ experiments, the fences were arranged such that the smooth side (without the horizontal stringers) faced the wind. Fences were supported by attaching three or four "feet" made from $2 \mathrm{~cm}$ wide steel angle to the lowest stringer and placing heavy $(>15 \mathrm{~kg}$ ) low-profile $(<5 \mathrm{~cm})$ weights on the feet. For most tests, two feet were installed $0.3 \mathrm{~m}$ to $0.4 \mathrm{~m}$ from the ends on one side, and one was installed at the center of the other side. Also, two or more cables (depending on the configuration) were connected to the fence to prevent the wind from blowing the fence over.

A pan that could accommodate a $5 \mathrm{~cm}$ bed of mulch was constructed and placed under the fence to allow testing of the effect of the presence of mulch which was a surrogate for any

combustible, fine-fuel ground cover. The sheet steel pan's dimensions were $1.1 \mathrm{~m}$ wide x $3.0 \mathrm{~m}$ long x $5 \mathrm{~cm}$ deep. The mulch was a shredded hardwood that was substantially dried in ambient sunlight, stored in a moderately-low-humidity indoor area, and then stored in an unconditioned space near the experiments. This conditioning was seen as sufficient in that realistic levels of moisture content were desired rather than artificially lower moisture as would occur from oven drying. Moisture content of the mulch was estimated to be similar to that of the fence wood. After higher wind speeds were found to blow mulch away from some pan areas before it had a chance to ignite, a chicken-wire mesh with $2.5 \mathrm{~cm}$ (1 in) openings was used to hold the mulch down. This was seen as a realistic measure given that most fine fuels on the ground in real fence installations would either be attached to the ground, such as grass or small plants, or compressed and interwoven together such as a weathered mulch bed.

\subsection{Wind}

The airboat wind source was loaned from the SSVFD. It was a $4.9 \mathrm{~m}(16 \mathrm{ft})$ Alumitech Airboat with a $280 \mathrm{~kW}(375 \mathrm{hp}) \mathrm{GM}-360 \mathrm{~V}-8$. It was fitted with a $1.83 \mathrm{~m}(6 \mathrm{ft})$ diameter, three blade propeller. Figure 3 is a photograph showing the airboat, top of the flow straightener, wind corridor walls, and fence. Preliminary testing of the airboat found that it was capable of producing winds well in excess of $18 \mathrm{~m} / \mathrm{s}$ (40 mph), although it was difficult to tell how far the wind field persisted and what the drop off in wind speed was with downwind and transverse distance from the prop. To counter the large-scale swirl produced by the airboat prop, a flow straightener was fabricated which consisted of two stacked $1.2 \mathrm{~m} \mathrm{x} 2.4 \mathrm{~m} \mathrm{(4ft} \mathrm{x} 8 \mathrm{ft})$ framed sections of $19 \mathrm{~mm}(3 / 4 \mathrm{in})$ cell aluminum honeycomb of $11 \mathrm{~cm}$ thickness. The flow straightener was angled downward $\approx 9^{\circ}$ for most tests (after Test 2 ) to provide better wind distribution at the leading edge of the fence base. Two plywood walls were constructed to create a wind corridor to better confine the wind flow and inhibit lower speeds at the outside edges of the fence area due

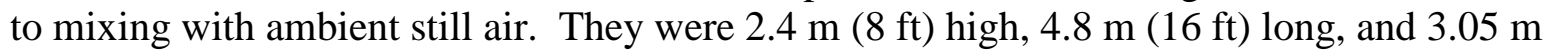
$(10 \mathrm{ft})$ apart.

The airboat was equipped with an automotive-type accelerator pedal which made maintaining a steady engine speed extremely difficult. A pedal locking device was constructed to allow the 
engine speed to be fixed very quickly after accelerating to the target level. The leading edge of

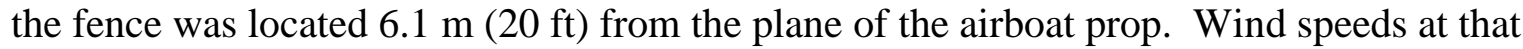
position were measured with a vane anemometer to be nominally $8.5 \mathrm{~m} / \mathrm{s}, 13.5 \mathrm{~m} / \mathrm{s}$, and $18 \mathrm{~m} / \mathrm{s}$ at engine speeds of $1300 \mathrm{~Hz}$ (revolutions per minute), $2000 \mathrm{~Hz}$, and $2700 \mathrm{~Hz}$, respectively. The uncertainty and spatial variation of the wind measurement are discussed later.

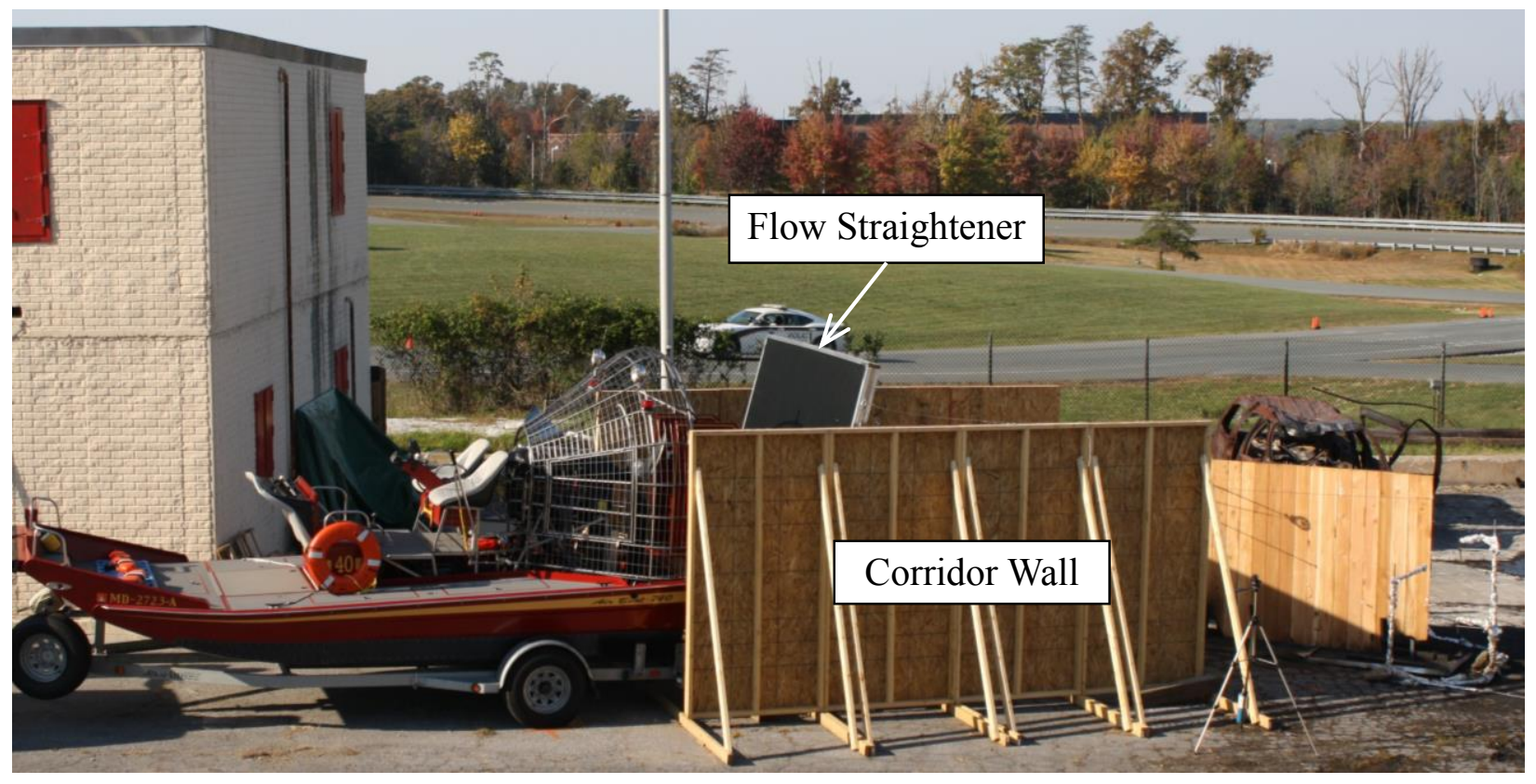

Figure 3 Photograph of the overall experimental set-up for the wind-driven fence fire spread experiments showing the airboat, angled flow straightener, corridor, and fence oriented at $45^{\circ}$.

\subsection{Firebrand Targets}

Four sets of $46 \mathrm{~cm}$ x $66 \mathrm{~cm}$ aluminum pans were used as firebrand targets to observe whether and how blown firebrands from the burning fence and mulch bed caused spotting of nearby combustibles. A photograph of a pair of targets is shown in Figure 4. One pan of each target pair was filled with about $2 \mathrm{~cm}(0.8 \mathrm{in})$ depth of mulch to see if firebrands could ignite it, and the other pan was filled with about $4 \mathrm{~mm}$ of water to capture the firebrands reaching that position for examination of their size and other characteristics. Four sets of targets were placed at $3.05 \mathrm{~m}$ $(10 \mathrm{ft})$ intervals downwind from the trailing edge of the fence along the centerline of the wind corridor. The trailing edge position relative to other fixed aspects of the test set-up varied with the orientation angle of the fence with the wind. For moderate or high wind speeds, the pans were weighted to prevent them from moving.

\subsection{Burner}

Firebrand ignition of fences has been studied and shown to be achievable [11] so this series of experiments was focused on fire spread while simulating an ignition by firebrands. A controlled and repeatable method of igniting the fence was needed since firebrand ignitions are not as repeatable and require firebrand generation equipment. The fence fires were ignited with a propane burner $30 \mathrm{~cm}(1 \mathrm{ft})$ from the leading end of the fence (or left end when looking 
downwind for the $90^{\circ}$ case), on the smooth side (except for one case described later). A flowmeter used to control the propane flow was set for $20 \mathrm{~L} / \mathrm{min}$, and the regulator was set at a delivery pressure of $103 \mathrm{kPa}(15 \mathrm{psig})$. The burner consisted of a $2 \mathrm{~cm}$ diameter brass tube with five $0.5 \mathrm{~mm}$ holes drilled $1 \mathrm{~cm}$ apart on the top and another five holes in the horizontal plane. The burner was oriented parallel to the bottom of the fence just at the mulch/fence interface and about $2 \mathrm{~cm}$ away from the fence.

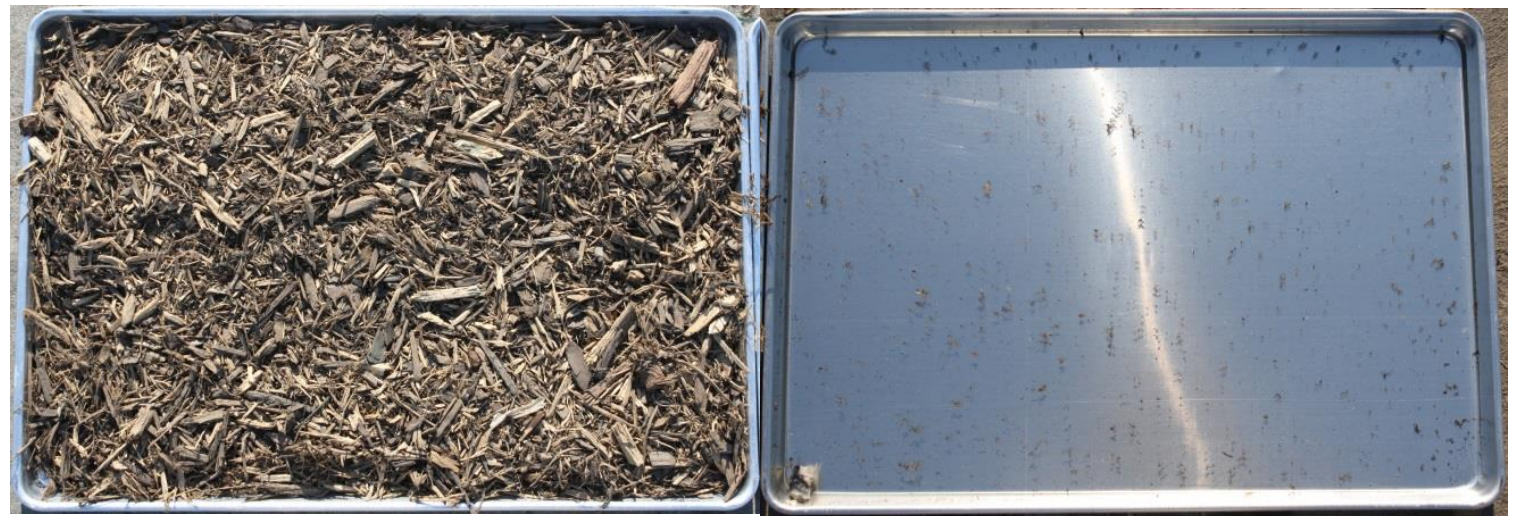

Figure 4 Photographs of a pair of firebrand targets after Test 7 (cedar at $45^{\circ}, 13.5 \mathrm{~m} / \mathrm{s}$ ). One pan is filled with about $2 \mathrm{~cm}$ of mulch (left) and the other contains about $4 \mathrm{~mm}$ of water (right). These were placed in $3.05 \mathrm{~m}$ intervals downwind of the trailing edge of the fence.

\subsection{Measurements}

In order to measure the wind velocity field, a grid of six bi-directional pressure probes was used with three arranged vertically at $30.5 \mathrm{~cm}, 91.4 \mathrm{~cm}$, and $152.4 \mathrm{~cm}$ heights (measured from the ground) on the centerline of the set-up and another three at the same heights but $91 \mathrm{~cm}$ off of the centerline. Figure 5 is a diagram showing the probe array arrangement. The probes were located in the same plane as the ends of the walls. Temperatures were measured with k-type thermocouple beads made from 24 AWG wire $(0.51 \mathrm{~mm}$ diameter) which had response times of approximately $1 \mathrm{~s}$ for the highest wind speeds. Ambient temperature was measured with thermocouples located near the pressure probes. Wind speed was calculated from the pressure and temperature measurements. The $18 \mathrm{~m} / \mathrm{s}$ wind speed profiles could only be partially measured because some pressure sensors over ranged, however that wind speed had been measured previously with a vane anemometer at the high centerline position.

Five thermocouples with high-temperature ceramic insulation were also stapled at $61 \mathrm{~cm}$ intervals along the fence to provide insight to fire spread if video tracking was obscured by smoke. Three water-cooled Schmidt-boelter heat flux gauges and an additional thermocouple were placed at the far end (away from the ignition point) of the fence to record the thermal insult that would impact any adjacent or adjoined structures in a real installation. A data acquisition system recorded 16 channels of measurement data every second and was used to plot the data during the test to allow monitoring of the devices and troubleshooting any malfunctions.

Four high-definition video cameras were placed around the fence to capture the fire and smoke behavior. The camera locations were on each side of the fence area (relative to the walls), 
upwind of the test area near the airboat, and up on a neighboring building looking down at the whole setup from one side. Figure 6 is a top view schematic of the experimental setup showing the relative positions of the video cameras for the three fence orientations. Digital still photographs were taken throughout the testing period and afterward.

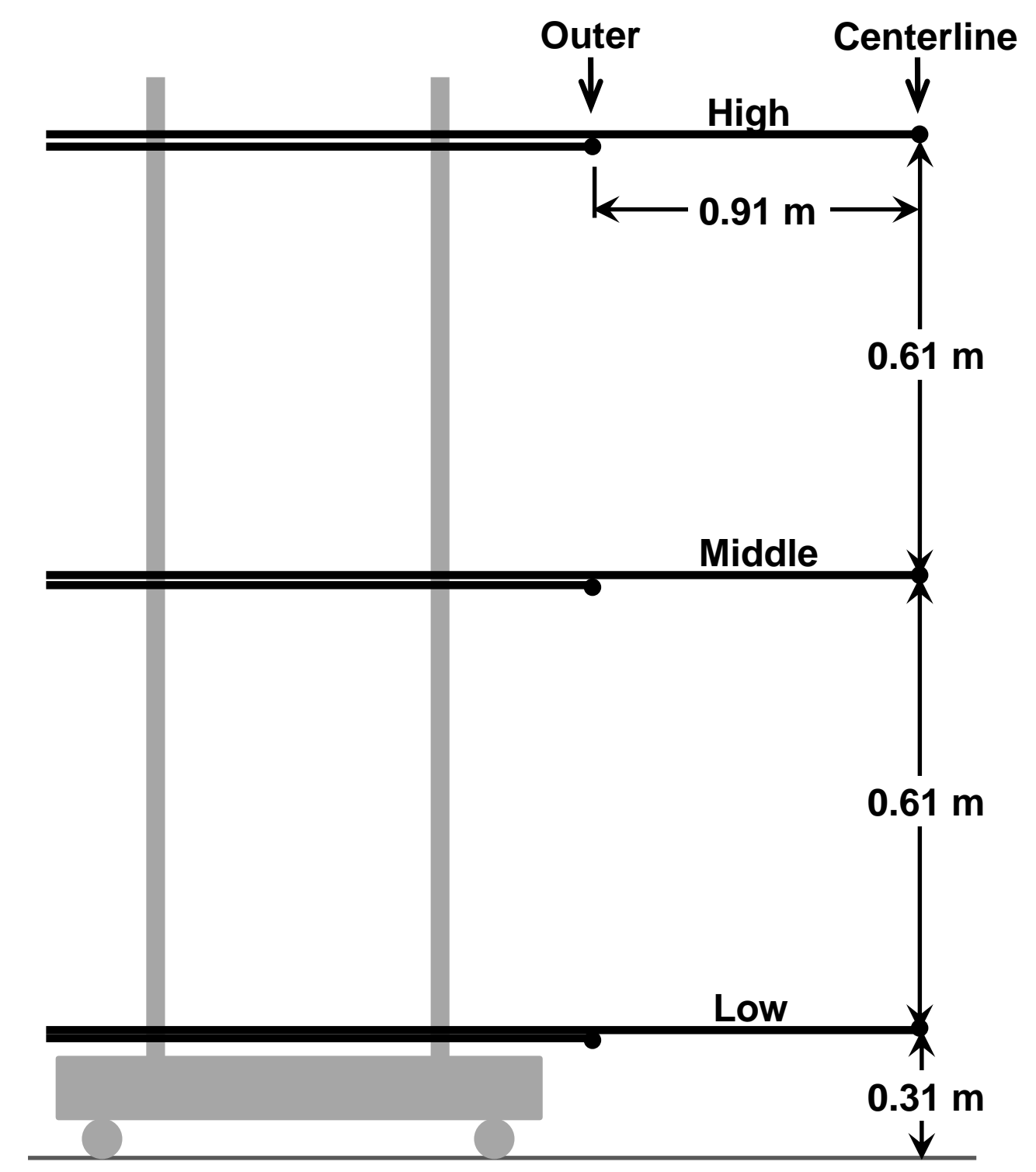

Figure 5 A diagram of the bi-directional probe array used to measure the velocity field.

\subsection{Conditions}

Table 1 lists the parameters tested and the number of conditions for each parameter. The primary variables were wind angle (fence orientation) and wind speed. After preliminary testing determined that the most extreme behavior or worst-case (fastest fire spread) conditions were $0^{\circ}$ angle, $13.5 \mathrm{~m} / \mathrm{s}(30 \mathrm{mph})$, and with mulch, subsequent focus studies of fence material and preservative coating were conducted under these conditions. Use of wire mesh on the mulch bed 
was found to be required for winds $13.5 \mathrm{~m} / \mathrm{s}$ and higher to prevent transport of mulch before it could become involved in a fire. Most experiments were conducted with western redcedar (hereafter referred to as "cedar") as the fence material, but two experiments were conducted with California redwood and one with vinyl fencing to compare their burning behavior. Two experiments, one with cedar and the other with redwood, were conducted with application of two coats of a commercially available wood preservative to observe whether the preservative affected the fire spread behavior. The preservative used was F\&P Finish and Preservative, an oil-based transparent exterior stain for decks and fences. The major components of the coating were Stoddard solvents, mineral oil, alkyd resin, deionized water, and wax emulsion.

Table 1 Parameters Explored. The parameters and number of conditions explored for each are listed.

\begin{tabular}{|l|c|c|c|}
\hline \multicolumn{1}{|c|}{ Parameters } & \multicolumn{3}{c|}{ Conditions } \\
\hline Material Type & $\begin{array}{c}\text { Western } \\
\text { Redcedar }\end{array}$ & $\begin{array}{c}\text { California } \\
\text { Redwood }\end{array}$ & Vinyl \\
\hline Preservative & Yes, No & Yes, No & No \\
\hline Mulch & Yes, No & Yes & Yes \\
\hline Mesh & Yes & Yes & Yes \\
\hline Angle $\left(^{\circ}\right)$ & $0,45,90$ & 0 & 0 \\
\hline Nominal Wind Speed (m/s) & $9,13^{1 / 2,18}$ & $13^{1 / 2}$ & $13^{1 / 2}$ \\
\hline
\end{tabular}

Table 2 lists all of the tests and their conditions. The Test 6 configuration differed from the other $45^{\circ}$ tests in that the burner ignited the fence on the structure side (the side with the horizontal stringers), and the fence was turned so the structure side faced the wind. Test 18 was conducted under only ambient conditions and no imposed wind. The top view schematic of Figure 6 shows the experimental setup including the relative positions of the fence, targets, and cameras for the three fence orientations.

\subsection{Procedures}

Preparation for a typical experiment was as follows. The mulch pan was located at the specified distance from the ends of the wall corridor and oriented at the specified angle. The fence section was then connected to the steel-angle feet and placed in the center of the mulch pan. Heavy steel bars were placed on the feet to hold the fence upright. Cables were attached between the corridor walls and the fence to keep it from swaying or blowing over. The airboat was warmed up for about 5 min to limit changes due to warming up during the experiment and to check the security of the fence and instrumentation before any mulch was installed. After the warm up was complete and the airboat stopped, approximately $170 \mathrm{~L}\left(6 \mathrm{ft}^{3}\right)$ of mulch was required to fill the mulch pan. The mulch was smoothed and lightly compressed to create a uniform bed. For most experiments, two lengths of chicken wire mesh were placed on the mulch, one on each side of the fence, such that the entire mulch bed was covered. Thermocouples were attached to the fence, and the burner, heat flux gauges, and video cameras were positioned. Pressure transducers" "zero" voltages were recorded while each bi-directional probe's openings were joined with plastic hose. Water lines for extinguishment were connected to a nearby hydrant and charged. Target pans were positioned relative to the fence and filled with mulch and water. Finally, a safety briefing regarding test procedure, participant roles, and safety reminders was conducted. 
Table 2 Test Matrix. Experimental conditions are listed for each experiment.

\begin{tabular}{|c|c|c|c|c|c|c|c|}
\hline $\begin{array}{l}\text { Test } \\
\text { No. }\end{array}$ & $\begin{array}{l}\text { Type of } \\
\text { Material }\end{array}$ & $\begin{array}{c}\text { Preservative } \\
(\mathbf{Y} / \mathbf{N})\end{array}$ & $\begin{array}{c}\text { Mulch } \\
(\mathbf{Y} / \mathbf{N})\end{array}$ & $\begin{array}{l}\text { Mesh } \\
(\mathbf{Y} / \mathbf{N})\end{array}$ & $\begin{array}{c}\text { Wind } \\
\text { Angle } \\
\left(^{\circ}\right)\end{array}$ & $\begin{array}{c}\text { Nominal } \\
\text { Wind } \\
\text { Speed } \\
(\mathrm{m} / \mathrm{s})\end{array}$ & $\begin{array}{c}\text { Angled Flow } \\
\text { Straightener } \\
\text { (Y/N) }\end{array}$ \\
\hline 1 & Cedar & $\mathrm{N}$ & $Y$ & $\mathrm{~N}$ & 90 & 9 & $\mathrm{~N}$ \\
\hline 2 & Cedar & $\mathrm{N}$ & $Y$ & $\mathrm{~N}$ & 0 & 9 & $\mathrm{~N}$ \\
\hline 3 & Cedar & $\mathrm{N}$ & $Y$ & $\mathrm{~N}$ & 0 & 9 & $\mathrm{Y}$ \\
\hline 4 & Cedar & $\mathrm{N}$ & $\mathrm{N}$ & $\mathrm{N}$ & 0 & $\begin{array}{c}18,131 / 2 \\
9\end{array}$ & $Y$ \\
\hline 5 & Cedar & $\mathrm{N}$ & $Y$ & $\mathrm{~N}$ & 45 & 9 & $Y$ \\
\hline 6 & Cedar & $\mathrm{N}$ & $Y$ & $\mathrm{~N}$ & 45 & 9 & $\mathrm{Y}$ \\
\hline 7 & Cedar & $\mathrm{N}$ & $\bar{Y}$ & $\mathrm{~N}$ & 45 & $13 \frac{1}{2}$ & $Y$ \\
\hline 8 & Cedar & $\mathrm{N}$ & $Y$ & $Y$ & 45 & $13 \frac{1}{2}$ & $Y$ \\
\hline 9 & Cedar & $\mathrm{N}$ & $\mathrm{Y}$ & $Y$ & 0 & $13 \frac{1}{2}$ & $Y$ \\
\hline 10 & Cedar & $\mathrm{N}$ & $\mathrm{Y}$ & $\mathrm{Y}$ & 0 & 18 & $\mathrm{Y}$ \\
\hline 11 & Redwood & $\mathrm{N}$ & $\mathrm{Y}$ & $\mathrm{Y}$ & 0 & $13 \frac{1}{2}$ & $Y$ \\
\hline 12 & Redwood & $Y$ & $Y$ & $Y$ & 0 & $131 / 2$ & $Y$ \\
\hline 13 & Cedar & $Y$ & $\bar{Y}$ & $Y$ & 0 & $13 \frac{1}{2}$ & $Y$ \\
\hline 14 & Cedar & $\mathrm{N}$ & $Y$ & $\mathrm{Y}$ & 0 & $13 \frac{1 / 2}{2}$ & $Y$ \\
\hline 15 & Cedar & $\mathrm{N}$ & $Y$ & $\mathrm{Y}$ & 0 & $13 \frac{1}{2}$ & $\mathrm{Y}$ \\
\hline 16 & Vinyl & $\mathrm{N}$ & $\mathrm{Y}$ & $\mathrm{Y}$ & 0 & $13 \frac{1}{2}$ & $\mathrm{Y}$ \\
\hline 17 & Cedar & $\mathrm{N}$ & Y & $\mathrm{N}$ & 90 & 9 & $\mathrm{Y}$ \\
\hline 18 & Cedar & $\mathrm{N}$ & Y & $\mathrm{N}$ & 90 & 0 & $\mathrm{Y}$ \\
\hline
\end{tabular}

Once preparation was complete, an experiment was conducted as follows. First, the data acquisition program was started. Next, the video cameras were started, and in order to facilitate synchronization of the videos later, the airboat operator blew the boat horn upon a visual signal from the test supervisor which was visible by the cameras. Then, the propane supply was opened to the burner, the pressure and flow were checked, and a lit pilot wand (long copper tube attached to a small propane bottle) was used to ignite the burner. The burner duration required to fully ignite the fence was typically $1 \mathrm{~min} 45 \mathrm{~s}$. At that point, the airboat operator was signaled to start the motor. Typically, the target engine speed was reached within $15 \mathrm{~s}$ to $25 \mathrm{~s}$. The burner propane was shut off, and digital photographs were taken of the fence, mulch bed, and targets to capture the progression of the fire and detailed burning behavior. The experiment was allowed to burn until the fire had spread to the end of the fence and there was no more significant localized burning of the mulch or fence or additional upward flame spread. For most experiments, this period lasted from $7 \mathrm{~min}$ to $13 \mathrm{~min}$ after the fire reached the end of the fence. At that point, the airboat engine was stopped and additional photographs were taken before water was applied to the fence and mulch bed. 


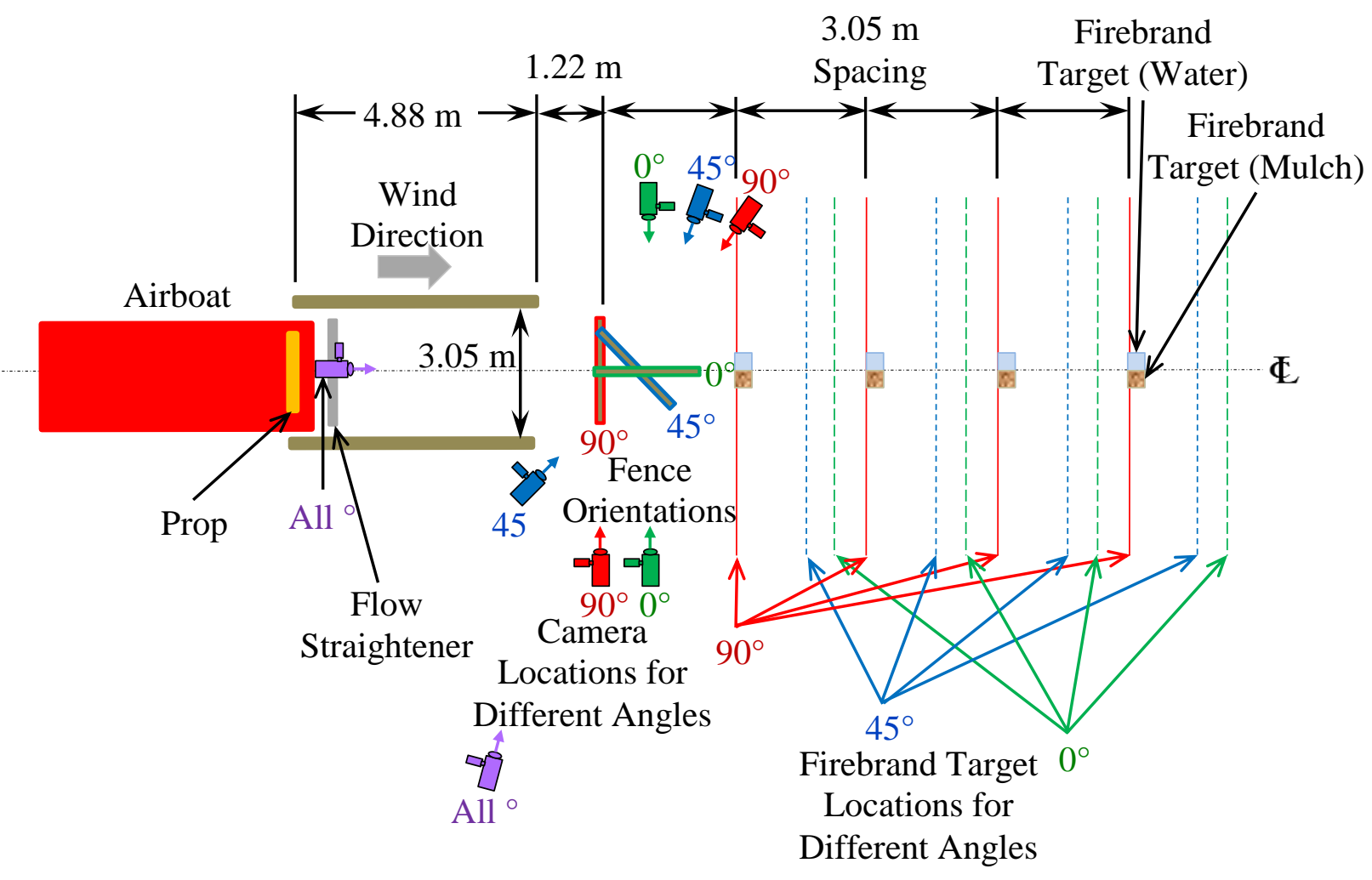

Figure 6 A top view schematic of the experimental setup showing the relative positions of the fence, firebrand targets, and video cameras for the three fence orientation angles.

\section{RESULTS AND DISCUSSION}

To aid in tracking fire spread in conjunction with the video recordings, a horizontal line of thermocouples was installed along the fence boards to gather temperature measurements. The tracking use for these temperatures was not required since video views were clear and unobscured by smoke. Also, the thermocouples were located $61 \mathrm{~cm}$ or higher on the fence, but the fires stayed unexpectedly close to the ground (often less than $10 \mathrm{~cm}$ ) and rarely progressed upward above about $50 \mathrm{~cm}$. Two difficulties in tracking the fire progress with the video record were that the wind-driven flames were intermittent and did not stay attached to the fuel for more than a fraction of a second, and the flames were located at the interface of the fence and mulch making it hard to determine which was truly burning.

To ascertain the thermal environment if there were an adjacent structure, two heat flux gauges and one thermocouple were deployed near the end of the fence (away from the ignited end). The thermal environment could not be effectively characterized by these sensors since they were also located too far above where the main fire was located. 


\subsection{Wind Field}

One objective of this experimental series was to determine the feasibility of utilizing an airboat as a reproducible, controlled, and realistic wind source for studying outdoor wind-driven fires. Before examining the wind-blown fire spread observations, it is sensible to present a discussion of the characteristics of the wind field generated by the airboat. Figure 7 shows a 4 min time trace of velocity on the centerline of the experiment and $91 \mathrm{~cm}$ above the ground for a nominal $13.5 \mathrm{~m} / \mathrm{s}$ imposed wind. The large fluctuations demonstrate the turbulent nature of the flow. Some of the fluctuations may be due to the bi-directional probes oscillating back and forth in the wind which could induce some pressure fluctuations not representative of the wind field. Whatever the sources of fluctuation, the resulting combined expanded uncertainty in the velocity measurements for this test is about $1.0 \mathrm{~m} / \mathrm{s}$. While this was typical, the uncertainty range for all wind speeds and locations was between $0.4 \mathrm{~m} / \mathrm{s}$ and $3.8 \mathrm{~m} / \mathrm{s}$.

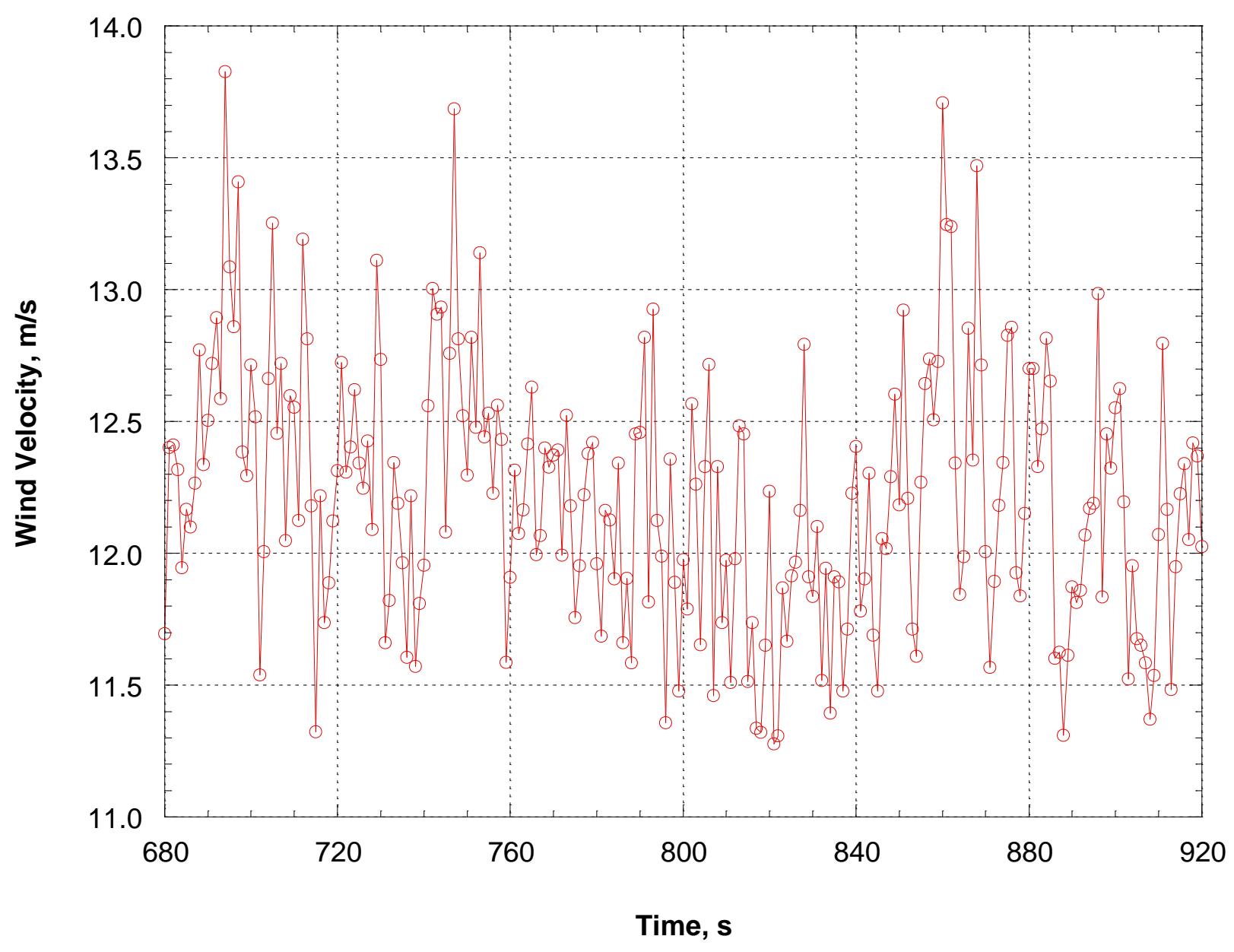

Figure $7 \mathrm{~A}$ plot of $4 \mathrm{~min}$ of velocity versus time data from the middle height $(0.91 \mathrm{~m}$ from ground) bidirectional probe on the centerline for Test $9\left(\right.$ cedar, $\left.0^{\circ}, 13.5 \mathrm{~m} / \mathrm{s}\right)$ showing the level of velocity fluctuations measured.

Figure 8 is a plot of the measured average velocity vertical profiles at the centerline for the experiments with a nominal $9 \mathrm{~m} / \mathrm{s}$ wind field. Measurements were taken at $30.5 \mathrm{~cm}, 91.4 \mathrm{~cm}$, and $152.4 \mathrm{~cm}$ from the ground at a distance of $1.22 \mathrm{~m}$ in front of the fence. Standard errors for 
the average velocities due to fluctuations ranged from $0.02 \mathrm{~m} / \mathrm{s}$ to $0.06 \mathrm{~m} / \mathrm{s}$. According to this data, the actual average velocities in the nominal $9 \mathrm{~m} / \mathrm{s}$ cases were between $7 \mathrm{~m} / \mathrm{s}$ and $8.5 \mathrm{~m} / \mathrm{s}$. The plot shows that the lowest height velocities were $1 \mathrm{~m} / \mathrm{s}$ to $2 \mathrm{~m} / \mathrm{s}$ less than those at the highest position. The middle height velocities were about halfway between those above and below except for the $45^{\circ}$ cases. The $45^{\circ}$ configuration produced markedly different profile shapes than the $0^{\circ}$ configuration. This difference could be due to the fence causing some angle-dependent upstream flow effects.

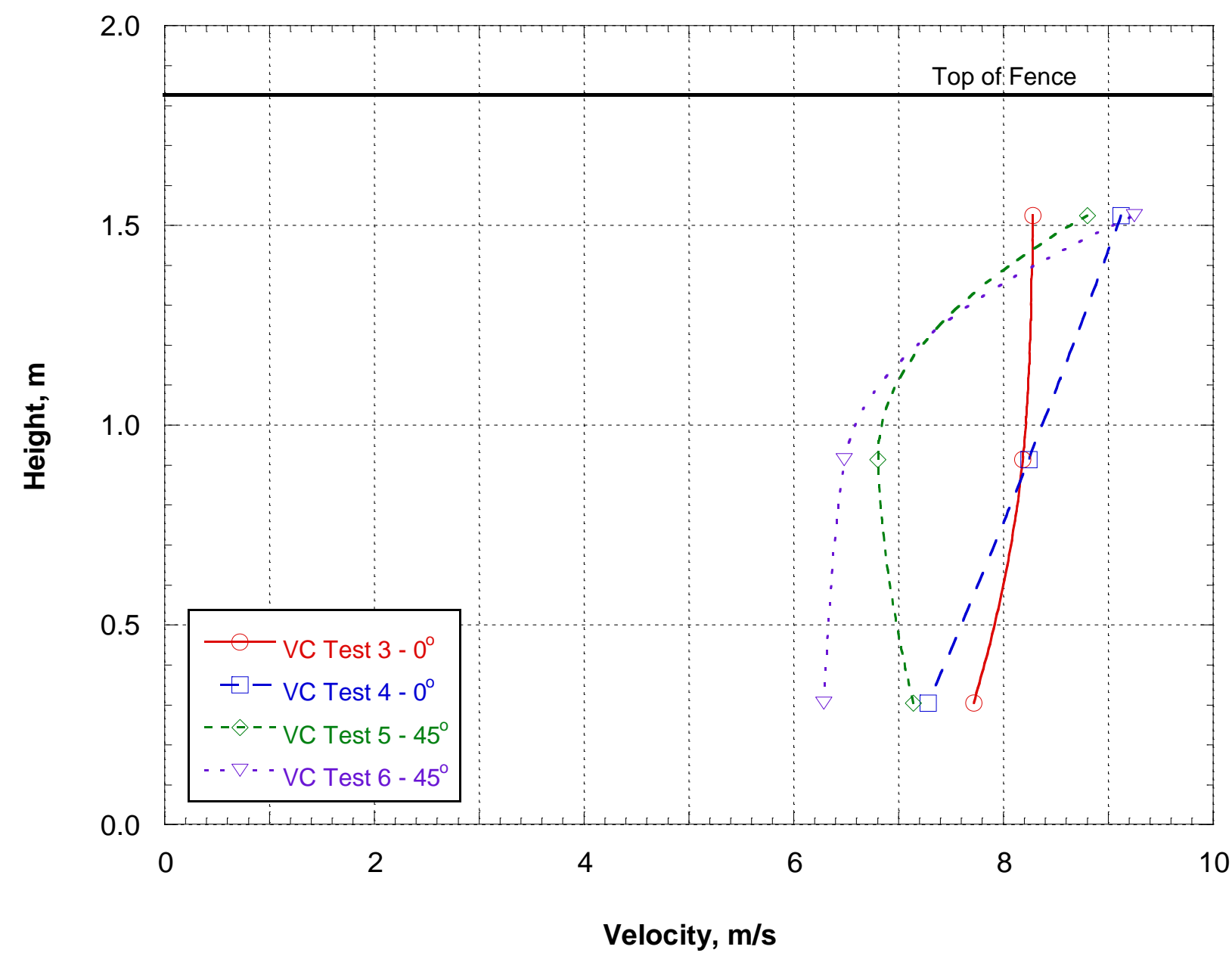

Figure 8 A plot of height versus velocity for the tests with complete vertical velocity data for the nominal wind speed of $9 \mathrm{~m} / \mathrm{s}$. The points represent the mean velocities during the steady wind period. Standard errors for the average velocities ranged from $0.02 \mathrm{~m} / \mathrm{s}$ to $0.06 \mathrm{~m} / \mathrm{s}$. Smooth curves were fit through the points to facilitate visualization of the profile.

The plot in Figure 9 is similar to the plot in Figure 8 but is for the nominal $13.5 \mathrm{~m} / \mathrm{s}$ cases. Because the pressure transducers had a maximum range of around $14.3 \mathrm{~m} / \mathrm{s}$, some data were truncated to that value and underestimated the true velocity and lowered the standard error. The maximum standard error for the average velocities due to fluctuations was $0.17 \mathrm{~m} / \mathrm{s}$, but typical standard errors were on the order of $0.04 \mathrm{~m} / \mathrm{s}$. The actual average velocities in the nominal $13.5 \mathrm{~m} / \mathrm{s}$ cases were between $10 \mathrm{~m} / \mathrm{s}$ and $12.5 \mathrm{~m} / \mathrm{s}$ (probably $13.5 \mathrm{~m} / \mathrm{s}$ considering the truncation of some of the data). The plot shows that the lowest height velocities were $2 \mathrm{~m} / \mathrm{s}$ to $4 \mathrm{~m} / \mathrm{s}$ less 
than those at the highest position. For the $0^{\circ}$ cases, the profiles were nearly linear with the middle height velocities about halfway between those above and below. For the $45^{\circ}$ cases, the profiles were markedly different than for $0^{\circ}$ and were not linear but showed large velocity changes between the middle and highest positions.

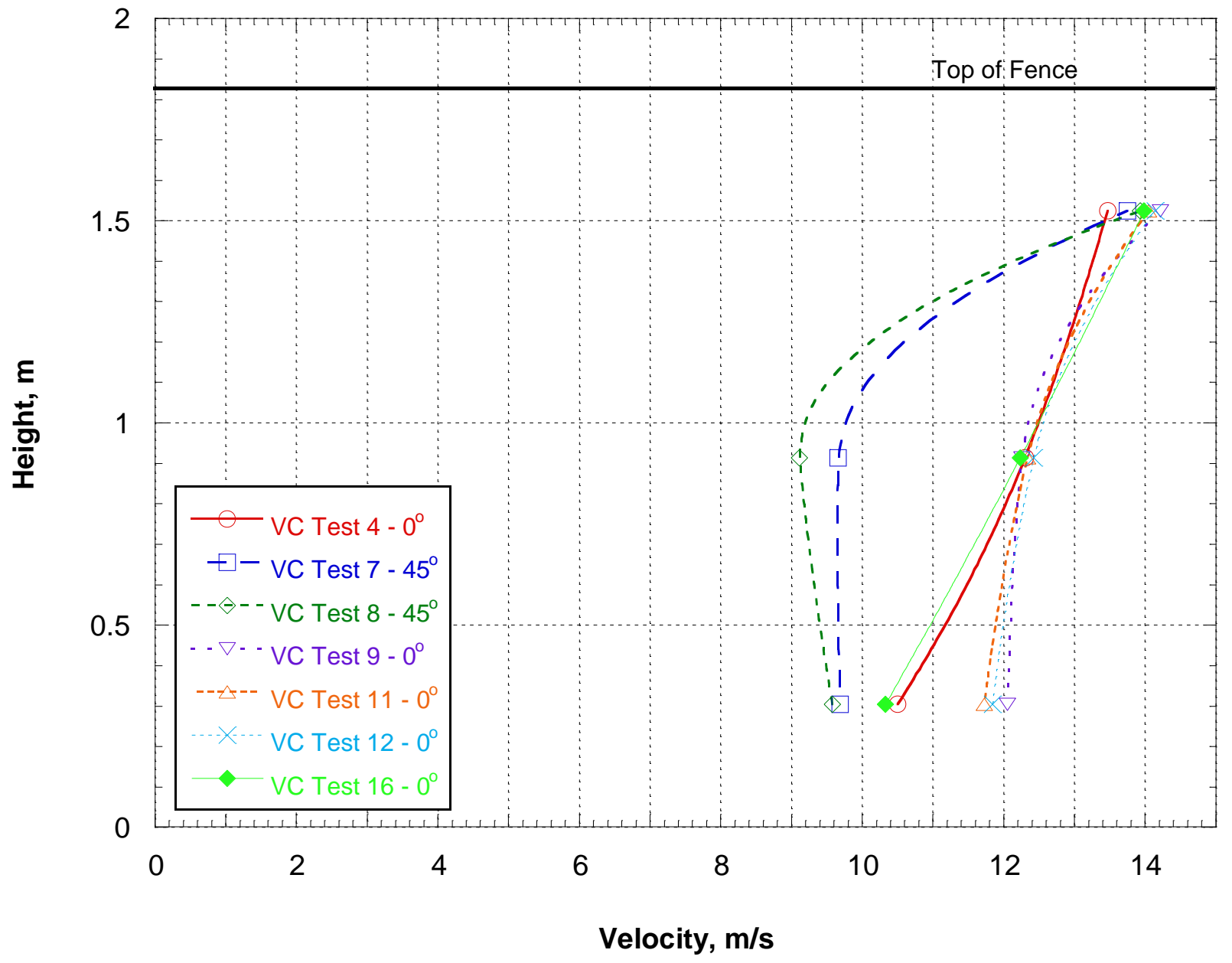

Figure 9 A plot of height versus velocity for the tests with complete vertical profile velocity data for the nominal wind speed of $13.5 \mathrm{~m} / \mathrm{s}$. The points represent the mean velocities during the steady wind period. Standard errors for the average velocities ranged from less than $0.01 \mathrm{~m} / \mathrm{s}$ to $0.17 \mathrm{~m} / \mathrm{s}$. Smooth curves were fit through the points to facilitate visualization of the profile.

Figure 10 is a plot of the measured average velocity horizontal profiles between the centerline and $91.4 \mathrm{~cm}$ from the centerline at the highest and middle heights for the experiments with a nominal $9 \mathrm{~m} / \mathrm{s}$ wind field. In the plot, the x-axis represents the ground, and the y-axis represents the center of the fence (but $1.22 \mathrm{~m}$ upstream). Open symbols represent the highest position $(152.4 \mathrm{~cm})$, and filled symbols represent the middle position $(91.4 \mathrm{~cm})$. Standard errors for the average velocities due to fluctuations ranged from $0.02 \mathrm{~m} / \mathrm{s}$ to $0.06 \mathrm{~m} / \mathrm{s}$. The plot shows that for most cases, the outer (away from the centerline) velocities are lower than those on the centerline, typically by $1 \mathrm{~m} / \mathrm{s}$ to $2 \mathrm{~m} / \mathrm{s}$. The middle height position for the $45^{\circ}$ configuration (Tests 5 and 6) had an inverted situation where the outer velocities were about $2 \mathrm{~m} / \mathrm{s}$ higher than those on the centerline. This again shows the possibility of some upstream effect of the fence which would have only impacted the centerline velocities. It also seems to only have affected the middle height and not the probes $1.5 \mathrm{~m}$ off of the ground. 


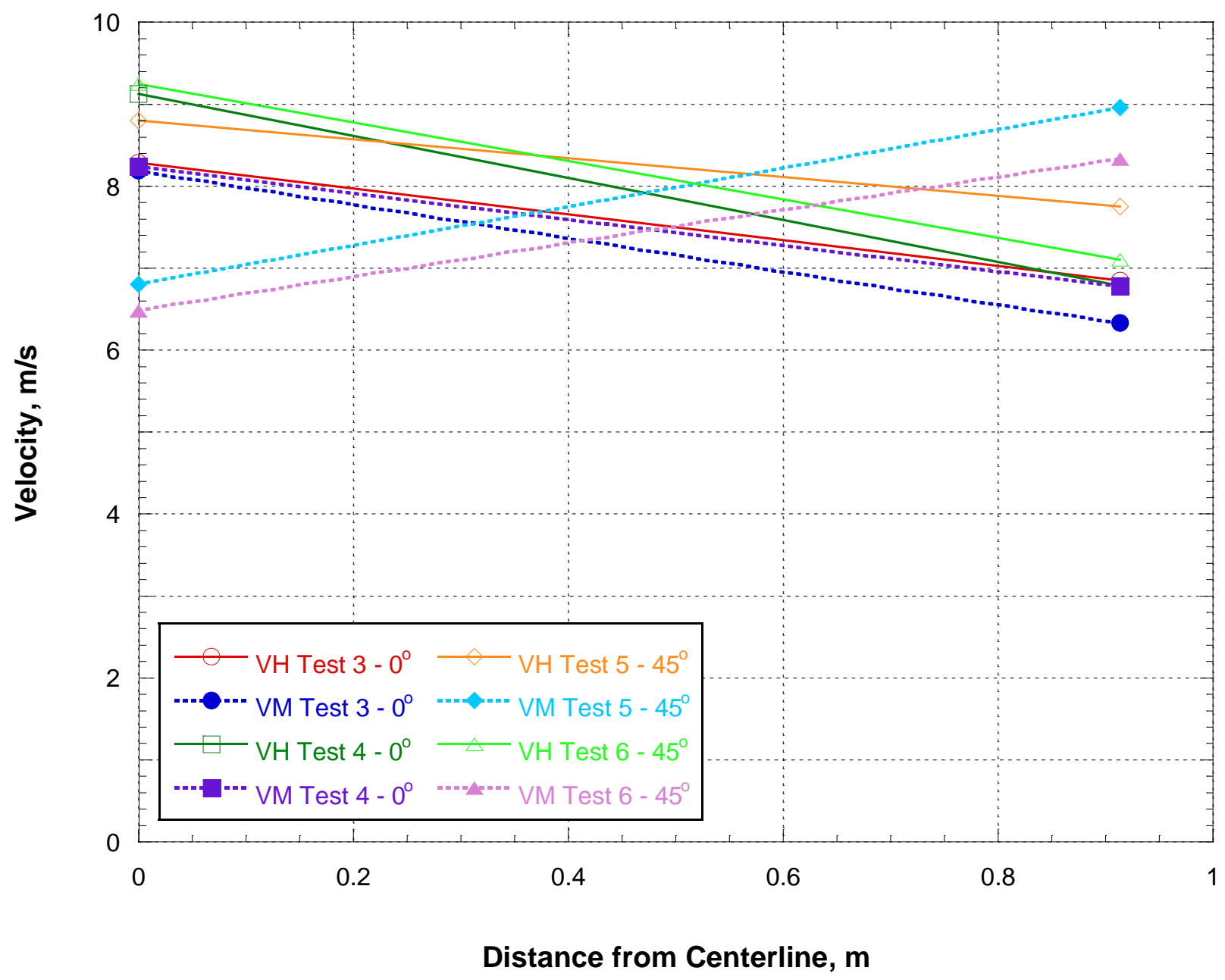

Figure $10 \mathrm{~A}$ plot of velocity versus distance from the centerline for the tests with complete horizontal profile velocity data for the nominal wind speed of $9 \mathrm{~m} / \mathrm{s}$. The points represent the mean velocities during the steady wind period. Standard errors for the average velocities ranged from $0.02 \mathrm{~m} / \mathrm{s}$ to $0.06 \mathrm{~m} / \mathrm{s}$. Lines were fit through the points to facilitate visualization of the profile.

The plot in Figure 11 is similar to the plot in Figure 10 but is for the nominal $13.5 \mathrm{~m} / \mathrm{s}$ cases. The maximum standard error for the average velocities due to fluctuations was $0.21 \mathrm{~m} / \mathrm{s}$, but typical standard errors were on the order of $0.05 \mathrm{~m} / \mathrm{s}$. The plot shows that for most cases, the outer (away from the centerline) velocities are lower than those on the centerline, typically by $2 \mathrm{~m} / \mathrm{s}$ to $3 \mathrm{~m} / \mathrm{s}$, but as much as $4.4 \mathrm{~m} / \mathrm{s}$ for the lowest position (Test 12 data). For Tests 4, 9, 11, and 12 , the centerline velocity for the middle position was only $1 \mathrm{~m} / \mathrm{s}$ higher than the outer velocity at the same position. The middle height position for the $45^{\circ}$ configuration (Tests 7 and 8) had an inverted situation where the outer velocities were higher by $2 \mathrm{~m} / \mathrm{s}$ to $3 \mathrm{~m} / \mathrm{s}$ than those on the centerline. Again, this possible upstream effect of the fence only impacted the centerline velocities at the middle height position.

The results of the airboat-generated wind field were encouraging in that the wind velocities generally dropped off from their maxima at the highest point on the centerline by only about $10 \%$ to $20 \%$ at lower heights and by about $10 \%$ to $35 \%$ away from the centerline except for 
the inverted exceptions discussed already. For future work, a larger wind field with a more uniform center will be sought, and care will be made to make measurements further upstream.

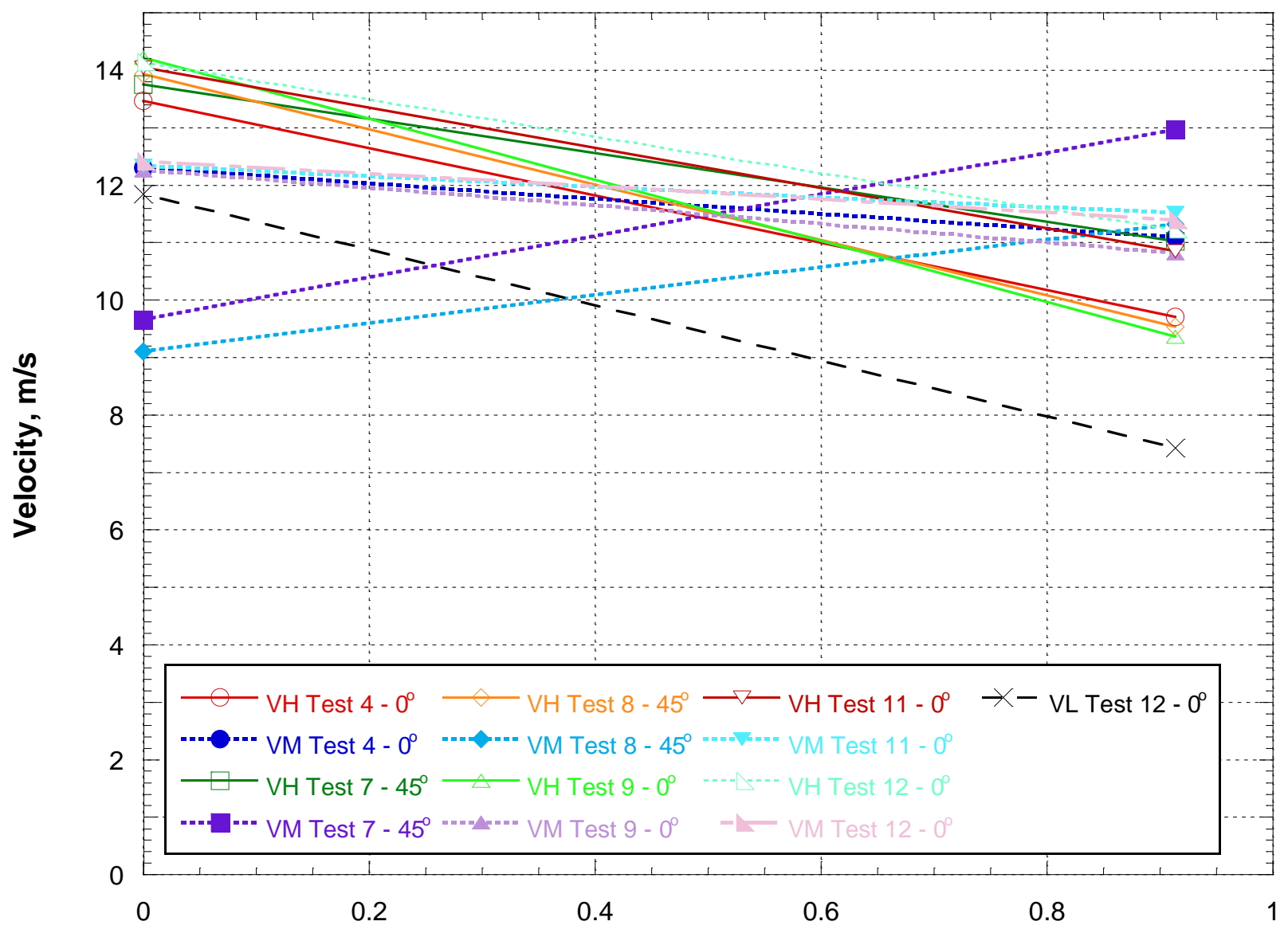

\section{Distance from Centerline, $\mathrm{m}$}

Figure 11 A plot of velocity versus distance from the centerline for the tests with complete horizontal profile velocity data for the nominal wind speed of $13.5 \mathrm{~m} / \mathrm{s}$. The points represent the mean velocities during the steady wind period. Standard errors for the average velocities ranged from less than $0.01 \mathrm{~m} / \mathrm{s}$ to $0.21 \mathrm{~m} / \mathrm{s}$. Lines were fit through the points to facilitate visualization of the profile.

\subsection{Effects of Mulch}

It was discovered during Test 4 with cedar and $0^{\circ}$ wind angle that for this type of fence, the presence of a combustible ground cover beneath the fence was significant. The mulch bed was essential to maintaining fire on the fence as fire spread did not progress without mulch present at any of the three wind speeds. Without mulch, the fence required reignition at each wind speed, and none of the velocity conditions supported sustained flaming. This is in contrast to the findings of Suzuki et al [11], but there are some differences in the configuration and situation. The Suzuki experiments utilized 20 min of sustained showers of actual wind-blown firebrands generated with a machine which caused piles of firebrands to accumulate and provide a sustained, distributed radiative and convective heat source to the fence. Smoldering ignition was observed in straight fence $\left(90^{\circ}\right)$ configuration and smoldering transitioning to flaming ignition 
was observed in a V-corner configuration. The Suzuki experiments without mulch provided a continuous source of heat (the firebrands) external to the fence while the experiments in this series relied on the previously ignited (under no wind) and smoldering (under wind) fence to self-sustain flame and even spread the fire without added heat from other sources. The ease of ignition of the thermally thin pieces of mulch and the mulch's radiation to the fence were essential for fire spread for these configurations and conditions tested. Further work is needed to understand what configurations and situations are most susceptible to ignition and persistent flame spread while exposed to high winds.

\subsection{Fire Spread}

Table 3 shows the times for fire to spread from the ignition point to the end of the fence for tests where this occurred. The tests have been reordered by material and wind angle. For most experiments, this distance was about $2.1 \mathrm{~m}$, but for Tests 17 and 18, the ignition point was in the center of the fence, and the distance to either end was only $1.2 \mathrm{~m}$. There are two columns for the time for fire spread; times for the first column were assessed using the video camera to the right of the experiment which usually viewed the smooth or windward side of the fence, and times for the second column used the video for the left, structure, or leeward side. The minimum times between the two sides are in shaded cells. The final column of Table 3 lists the maximum rate of fire spread calculated for each experiment. The combined expanded uncertainty in the time estimates is about $\pm 6 \mathrm{~s}$ which translates to a maximum of $\pm 7 \%$ for the fastest fire spread rate.

Test 18 for cedar in the $90^{\circ}$ configuration but with no imposed wind was the control for the experiments. It exhibited very limited fire spread. Test 1 with cedar, $90^{\circ}$ angle, and $9 \mathrm{~m} / \mathrm{s}$ wind did not have the wind angled downward from the airboat and experienced very slow fire spread of only $7 \mathrm{~cm} / \mathrm{min}$. The wind appeared to hit the mulch and fence beyond the ignited area and even direction reversal was observed at low heights. Test 17 was the same configuration as Test 1 , but with the angled wind, and the fire still did not spread beyond the ignition area of the fence. Due to the angled wind field, the wind hit the flames directly and strained the flames substantially more in Test 17 than in Test 1 . From either case, the $90^{\circ}$ angle appears to be the least conducive to fire spread due to the stagnation condition.

The $45^{\circ}$ experiments with cedar and wind at $9 \mathrm{~m} / \mathrm{s}$ (Tests 5 and 6) experienced faster average fire spread $(1.13 \mathrm{~m} / \mathrm{min})$ than the higher wind speed Tests (Tests 7 and 8 ) at $45^{\circ}$ and $13.5 \mathrm{~m} / \mathrm{s}$ which ranged from $0.57 \mathrm{~m} / \mathrm{min}$ to $0.28 \mathrm{~m} / \mathrm{min}$, respectively, and averaged $0.42 \mathrm{~m} / \mathrm{min}$. The $45^{\circ}$ angle and $9 \mathrm{~m} / \mathrm{s}$ wind condition was considered as a candidate for the "standard" configuration to test the effects of preservative and material until a faster spread rate configuration was found.

The $0^{\circ}$ angle orientation would be expected to exhibit fast fire spread due to the alignment of the fence with the wind, and it was found to be true under some wind conditions. For the first experiment at this angle, Test 2 , the wind field tended to reverse at low heights and the fire progression was very slow (only $8 \mathrm{~cm} / \mathrm{min}$ ) which revealed the non-uniform vertical wind profile being generated from the airboat. Once the flow straightener was angled downward by about $9^{\circ}$, the fence and mulch bed were exposed to a fairly uniform wind field vertically. 
Table 3 Fire Spread Results. Times for fire spread for those experiments which burned from the ignition point to the end of the fence under one set of conditions.

\begin{tabular}{|c|c|c|c|c|c|c|c|}
\hline $\begin{array}{l}\text { Test } \\
\text { No. }\end{array}$ & $\begin{array}{c}\text { Type } \\
\text { of } \\
\text { Mater- } \\
\text { ial }\end{array}$ & $\begin{array}{c}\text { Wind } \\
\text { Angle } \\
\left(^{\circ}\right)\end{array}$ & $\begin{array}{c}\text { Nominal } \\
\text { Wind } \\
\text { Speed } \\
(\mathrm{m} / \mathrm{s})\end{array}$ & $\begin{array}{c}\text { Angled } \\
\text { Flow } \\
\text { Straight- } \\
\text { ener } \\
(\mathrm{Y} / \mathrm{N})\end{array}$ & $\begin{array}{l}\text { Time for Fire } \\
\text { Spread } \\
\text { Viewed from } \\
\text { Smooth, } \\
\text { Windward, } \\
\text { or Right Side } \\
\text { (min:s) }\end{array}$ & $\begin{array}{c}\text { Time for } \\
\text { Fire Spread } \\
\text { Viewed } \\
\text { from } \\
\text { Structure, } \\
\text { Lee, or Left } \\
\text { Side } \\
\text { (min:s) } \\
\end{array}$ & $\begin{array}{c}\text { Fastest } \\
\text { Horizontal } \\
\text { Fire } \\
\text { Spread } \\
\text { Rate } \\
\text { (m/min) }\end{array}$ \\
\hline 18 & Cedar & 90 & 0 & $Y$ & & & \\
\hline 1 & Cedar & 90 & 9 & $\mathrm{~N}$ & $29: 33$ & $43: 24$ & 0.07 \\
\hline 17 & Cedar & 90 & 9 & $Y$ & & & \\
\hline 5 & Cedar & 45 & 9 & $\bar{Y}$ & $1: 50$ & $2: 21$ & 1.16 \\
\hline 6 & Cedar & 45 & 9 & $Y$ & $2: 14$ & $1: 56$ & 1.1 \\
\hline 7 & Cedar & 45 & $131 / 2$ & $\bar{Y}$ & $3: 55$ & $3: 45$ & 0.57 \\
\hline 8 & Cedar & 45 & $131 / 2$ & $\mathrm{Y}$ & $7: 43$ & $7: 47$ & 0.28 \\
\hline 4 & Cedar & 0 & $\begin{array}{c}18,13^{1 / 2}, \\
9\end{array}$ & Y & & & \\
\hline 2 & Cedar & 0 & 9 & $\mathrm{~N}$ & $27: 01$ & $25: 35$ & 0.08 \\
\hline 3 & Cedar & 0 & 9 & $\mathrm{Y}$ & $4: 52$ & $4: 49$ & 0.44 \\
\hline 9 & Cedar & 0 & $131 / 2$ & $\mathrm{Y}$ & $1: 54$ & $1: 37$ & 1.32 \\
\hline 14 & Cedar & 0 & $13 \frac{1}{2}$ & $\mathrm{Y}$ & $4: 44$ & $4: 31$ & 0.47 \\
\hline 15 & Cedar & 0 & $13 \frac{1}{2}$ & $Y$ & $3: 36$ & $3: 12$ & 0.67 \\
\hline 13 & $\begin{array}{c}\text { Cedar/P } \\
\text { res. }\end{array}$ & 0 & $13 \frac{1}{2}$ & Y & $3: 46$ & $3: 30$ & 0.61 \\
\hline 11 & $\begin{array}{l}\text { Red- } \\
\text { wood }\end{array}$ & 0 & $13 \frac{1}{2}$ & Y & $2: 07$ & $1: 51$ & 1.15 \\
\hline 12 & $\begin{array}{l}\text { Red- } \\
\text { wood/ } \\
\text { Pres. } \\
\end{array}$ & 0 & $13 \frac{1}{2}$ & Y & $1: 57$ & $1: 29$ & 1.44 \\
\hline 16 & Vinyl & 0 & $131 / 2$ & $\bar{Y}$ & $3: 55$ & $7: 15$ & 0.54 \\
\hline 10 & Cedar & 0 & 18 & $Y$ & $2: 07$ & $2: 11$ & 1.01 \\
\hline
\end{tabular}

The horizontal fire spread rate for Test 3 with $9 \mathrm{~m} / \mathrm{s}$ wind was only $0.44 \mathrm{~m} / \mathrm{min}$ which was much slower than the $45^{\circ}$ experiments at the same wind speed. However, Test 9 at $13.5 \mathrm{~m} / \mathrm{s}$ demonstrated a fire spread rate of $1.32 \mathrm{~m} / \mathrm{min}$ on the structure side of the fence which was faster than the fastest $45^{\circ}$ experiment so the configuration of $0^{\circ}$ angle and $13.5 \mathrm{~m} / \mathrm{s}$ was chosen as the "worst case" scenario used for subsequent testing to assess the differences between redwood, cedar, and vinyl and the effects of preservative on cedar and redwood. Two later repeats of the $0^{\circ}, 13.5 \mathrm{~m} / \mathrm{s}$ configuration with cedar (Tests 14 and 15) actually exhibited lower fire spread rates so the wide range of results makes it unclear whether this configuration was really the "worst case". Test 10 with $0^{\circ}$ and $18 \mathrm{~m} / \mathrm{s}$ resulted in a slightly slower fire spread rate of $1.01 \mathrm{~m} / \mathrm{min}$. 
This wind velocity was high enough that mulch tended to erode from the bed even with the wire mesh in place.

The maximum horizontal fire spread rate was $1.44 \mathrm{~m} / \mathrm{min}$ for Test 12 which was redwood with preservative at $0^{\circ}$ and $13.5 \mathrm{~m} / \mathrm{s}$ wind. Since the uncertainty for this fire spread rate is about $\pm 7 \%$, the difference between Test 12's spread rate and Test 9's for cedar at $0^{\circ}$ and $13.5 \mathrm{~m} / \mathrm{s}$ wind $(1.32 \mathrm{~m} / \mathrm{min})$ is statistically insignificant. One interesting pattern to note in Table 3 is that for most cases with wood fences and $0^{\circ}$ angle, the structure side experienced the fastest fire spread.

\subsection{Effects of Other Variables}

The angled flow straightener exposed the fence and mulch bed to a fairly uniform wind field vertically. The necessity of this was discovered during Tests 1 and 2 when the wind field tended to reverse at low heights and the fire progression was very slow.

The straight sections of fence need to stay upright and rigid to simulate real fence sections installed in the ground. To do this required the steel "feet" attached to the horizontal stringers as well as some cabling. The feet were made of $2 \mathrm{~cm}$ angle for strength, but this also created a slight obstacle for the wind, and small stagnation and recirculation zones formed when the fire passed by them. It does not seem that the feet impeded the downwind fire spread but they did enhance some localized upward burning as can be seen in Figure 12 (bottom right photograph).

Cedar and redwood fire spread rate differences were not significant. In Table 3, Tests 9, 13, and 14 were conducted with cedar at $0^{\circ}$ and $13.5 \mathrm{~m} / \mathrm{s}$ wind while Test 11 was conducted with redwood and the same conditions. While the fire spread rate for redwood was $1.44 \mathrm{~m} / \mathrm{min}$, and this was faster than the average spread rate of $0.77 \mathrm{~m} / \mathrm{min}$ for the cedar, there was a similarly fast spread rate of $1.32 \mathrm{~m} / \mathrm{min}$ on cedar during Test 9 . The apparent natural variation of the spread rates, the uncertainty in the timing, and the fact that only one test was conducted on untreated redwood make drawing any conclusions about the differences between California redwood and western redcedar problematic. The most conclusive statement that can be made is that the two materials performed similarly and that the single redwood test result was similar to the fastest cedar result. Additional redwood experiments should be conducted to verify this finding.

Tests 5 and 6 were under identical conditions of $45^{\circ}$ and nominal $13.5 \mathrm{~m} / \mathrm{s}$ wind speed, but the fence in Test 6 was turned such that the structure side faced the wind. The ignition still occurred on the windward side. Table 3 shows that there was no significant difference in the fire spread rate between the two orientations.

Fire spread rate differences due to two coats of wood preservative were not significant, but burning behavior differences were observed. In Table 3, the spread times for Test 13, cedar with preservative, an orientation angle of $0^{\circ}$, and nominal wind speed of $13.5 \mathrm{~m} / \mathrm{s}$, were around the average for Tests 9, 14, 15 which were conducted with the same wood, angle, and wind speed but without preservative. For redwood under the same wind speed and angle, Test 12 with preservative experienced fire spread rates on the smooth and structure sides which were $9 \%$ and $24 \%$ higher, respectively, than the rates on the same sides for Test 11 without preservative. 
Since only one test of each type was performed, the results aren't statistically significant, but it can be said that the spread rates were among the fastest tested and were similar despite the preservative. There were some qualitative differences when preservative was used compared to the cases when it wasn't. After the wind was stopped, the non-preserved wood generally stopped burning within about $2 \mathrm{~min}$, but for the cedar with preservative, the flames continued on the fence for about $4 \mathrm{~min}$, and for redwood with preservative they lasted about $5 \mathrm{~min}$. Also, for preserved redwood, the post-wind flames burned upward past the middle horizontal $2 \times 4$ to about $1.04 \mathrm{~m}$ which was further than for any other experiment. A close-up photograph of the preserved-cedar experiment in Figure 13 shows the attached flames along the bottom of the fence boards. The Figure 14 photograph taken during the preserved-redwood experiment shows the whole structure side of the fence with substantial burning taking place.
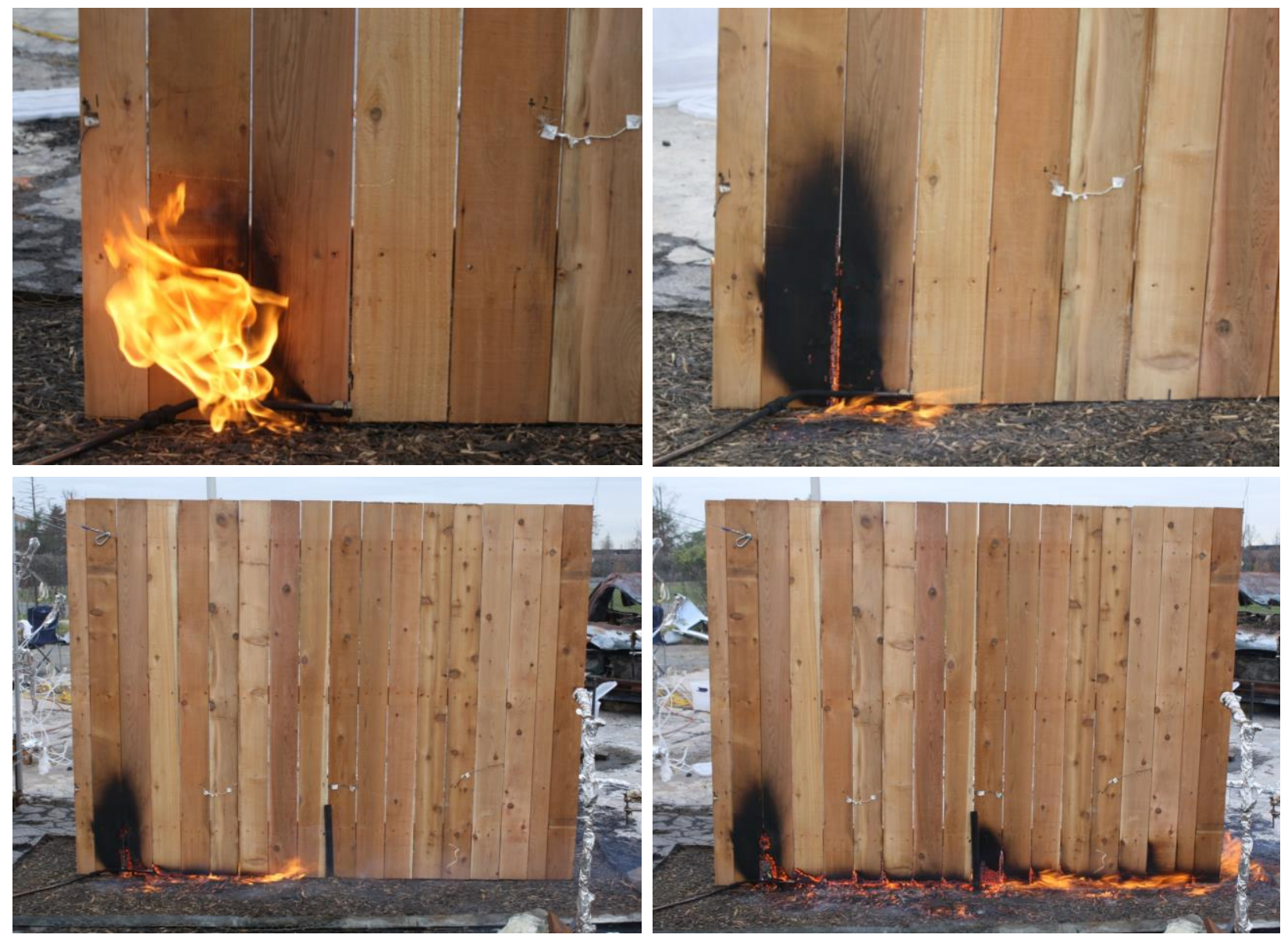

Figure 12 Photographs of Test 15 (cedar at $0^{\circ}, 13.5 \mathrm{~m} / \mathrm{s}$ ) showing progression of the fire: ignition (UL), initial wind-blown fire (UR), spread to half of the fence (BL), and spread to the full fence (BR). Wind direction was left to right.

Vinyl fence fires can vary qualitatively from wood fence fires due to structural differences and heated material behavior differences. The vinyl fence seemed to ignite, but upon initiation of the wind, the flames disappeared from view. Only about 4 min later did it become obvious that the fire had slowly spread forward inside the hollow lower horizontal member of the fence. After spreading along the whole length, the heat from the internal fire began to weaken the structure of the fence and eventually, the vertical "boards" blew off in the wind and the fence collapsed. Few 
firebrands were apparently generated from the vinyl fence due to the cohesive nature of the thermoplastic material. Some pieces of vinyl char were spotted in the mulch targets, but they did not seem to ignite any mulch. It is noteworthy that the mulch bed under the fence did not burn very extensively ( $1 / 3$ of the mass) compared to the degree seen during wood fence experiments. Unlike the vinyl and mulch combination, the burning wood and mulch apparently depended on thermal radiation exchange in a synergistic fashion causing both to burn more vigorously.

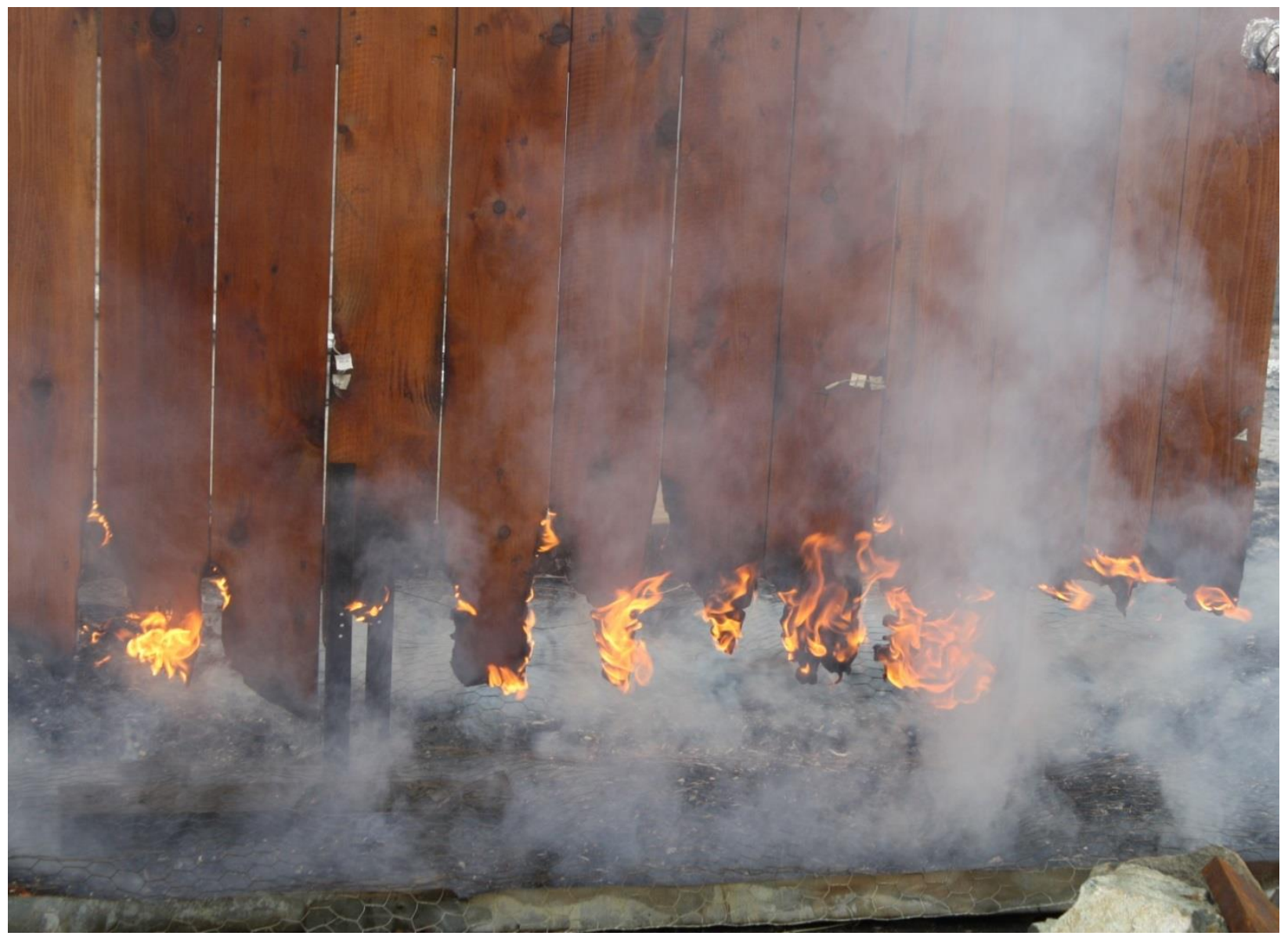

Figure 13 Photograph from Test 13 (preservative-coated cedar at $0^{\circ}, 13.5 \mathrm{~m} / \mathrm{s}$ ) showing flames attached to several fence boards and a significant amount of material burned away from the board ends. Wind direction was left to right.

\subsection{Firebrand Targets}

Table 4 shows the mulch ignitions in the targets spaced $3.05 \mathrm{~m}, 6.10 \mathrm{~m}, 9.14 \mathrm{~m}$, and $12.19 \mathrm{~m}$ downwind from the trailing edge of the fence. The cases when ignitions were found are also shaded. The $9.14 \mathrm{~m}$ target in Test 10 was blown over by the wind before any ignitions could be viewed. From these results, it appears that a wind speed greater than $9 \mathrm{~m} / \mathrm{s}$ was required for firebrands to ignite these particular targets at their locations. Also, the $0^{\circ}$ angle orientation caused ignitions at further distances from the fence than the $45^{\circ}$ angle did. This is probably due to the substantial diversion of firebrands by the deflection of the wind along the $45^{\circ}$ fence line. 
After fire burned away the bottom of the fence, a path was made for wind to penetrate under the fence to loft firebrands, and more were able to progress along the centerline of the set-up.

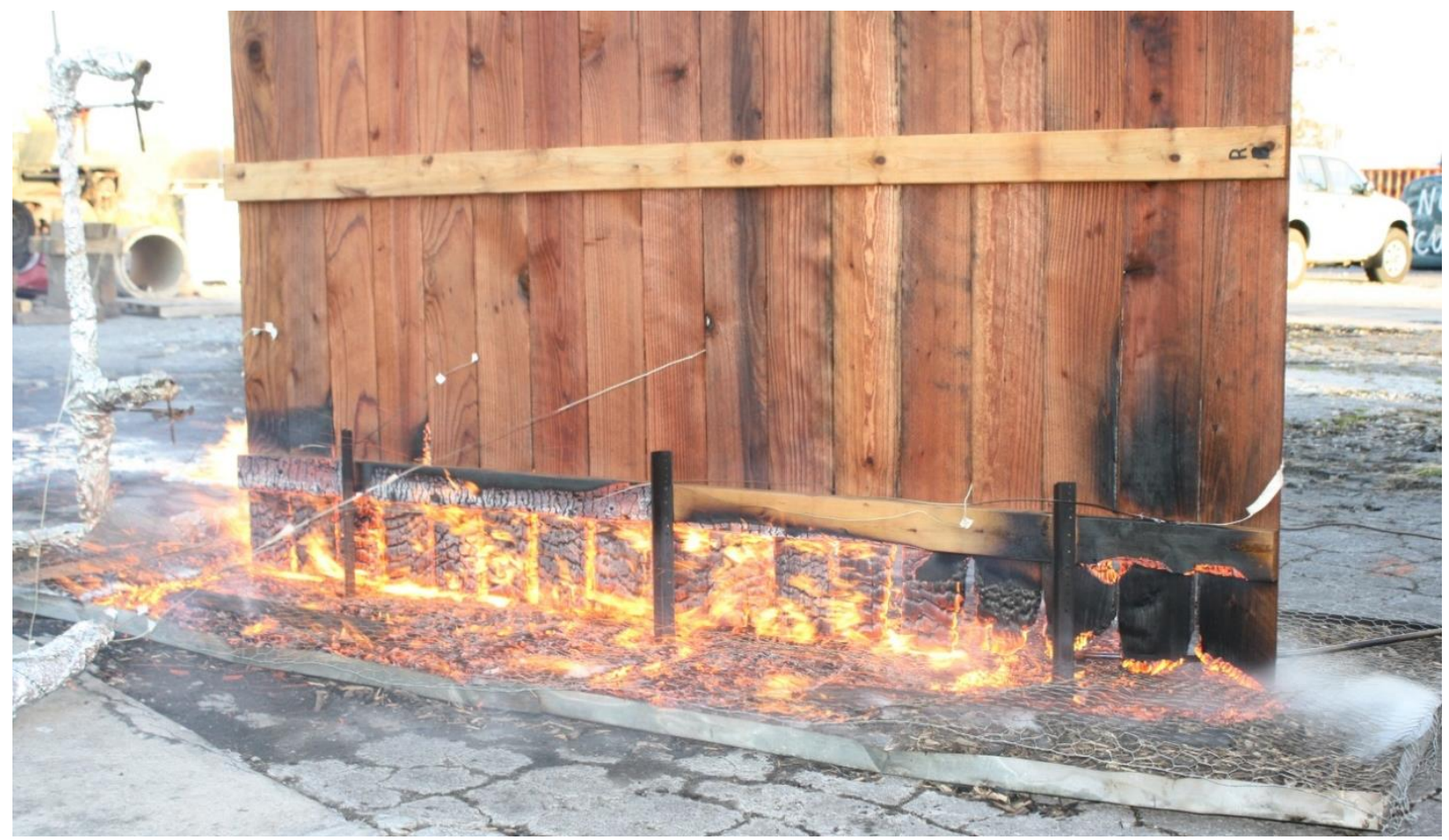

Figure 14 Photograph from Test 12 (preservative-coated redwood at $0^{\circ}, 13.5 \mathrm{~m} / \mathrm{s}$ ) showing substantial burning of the lower $2 / 3$ of the structure side of the fence after the fire progressed (from right to left) to the end.

It is interesting that for some experiments $(10,12$, and 15), mid-range targets (at $6.10 \mathrm{~m}$ or $9.14 \mathrm{~m}$ ) experienced no ignitions while the furthest downwind target (at $12.19 \mathrm{~m}$ ) did ignite. This was due to the random nature of the firebrand accumulation in the targets and the relatively low density of firebrands being spread over a large downwind area. Mulch was needed to cause substantial fire spread, and mulch firebrands were also responsible for many of the ignitions based on photographic analysis of the mulch and water targets. Figure 15 shows three photographs during Test 9 (cedar at $\left.0^{\circ}, 13.5 \mathrm{~m} / \mathrm{s}\right)$ with different perspectives on the first $(3.05 \mathrm{~m})$ mulch pan which was ignited by mulch-generated firebrands. Some fence-generated firebrands were also involved as can be seen in Figure 16 when during Test 12 (preservative-coated redwood at $\left.0^{\circ}, 13.5 \mathrm{~m} / \mathrm{s}\right)$ a large firebrand $(5 \mathrm{~cm} \times 8 \mathrm{~cm} \times 1.5 \mathrm{~cm})$ was captured in the first water target $3.05 \mathrm{~m}$ from the fence. Vinyl firebrands and even the mulch firebrands in the vinyl fence test were not successful at generating ignitions for the conditions studied here.

In some experiments, fence and mulch firebrands were blown substantially further than the furthest target, and some downwind ignitions of combustibles were seen. As an example, Figure 17 shows photographs of a weathered and cracked railroad tie type of timber located over $18 \mathrm{~m}$ from the fence. The timber (upper left photograph) was ignited in at least two locations where firebrands accumulated in cracks. The lower left photograph shows the firebrand shower near the timber. 
Table 4 Firebrand Target Results. Incidence of mulch ignition in targets spaced $3.05 \mathrm{~m}, 6.1 \mathrm{~m}, 9.14 \mathrm{~m}$, and $12.19 \mathrm{~m}$ downwind from the trailing edge of the fence.

\begin{tabular}{|c|c|c|c|c|c|c|c|c|}
\hline \multirow{2}{*}{$\begin{array}{l}\text { Test } \\
\text { No. }\end{array}$} & \multirow{2}{*}{$\begin{array}{l}\text { Type of } \\
\text { Material }\end{array}$} & \multirow{2}{*}{$\begin{array}{c}\text { Wind } \\
\text { Angle } \\
\left(^{\circ}\right)\end{array}$} & \multirow{2}{*}{$\begin{array}{c}\text { Nominal } \\
\text { Wind } \\
\text { Speed } \\
(\mathrm{m} / \mathrm{s})\end{array}$} & \multirow{2}{*}{$\begin{array}{c}\text { Angled } \\
\text { Flow } \\
\text { Straight- } \\
\text { ener } \\
\text { (Y/N) }\end{array}$} & \multicolumn{4}{|c|}{ Firebrand Target Ignition } \\
\hline & & & & & $3.05 \mathrm{~m}$ & $6.10 \mathrm{~m}$ & $9.14 \mathrm{~m}$ & $12.19 \mathrm{~m}$ \\
\hline 18 & Cedar & 90 & 0 & $\mathrm{Y}$ & $\mathrm{N}$ & $\mathrm{N}$ & $\mathrm{N}$ & $\mathrm{N}$ \\
\hline 1 & Cedar & 90 & 9 & $\mathrm{~N}$ & $\mathrm{~N}$ & $\mathrm{~N}$ & $\mathrm{~N}$ & $\mathrm{~N}$ \\
\hline 17 & Cedar & 90 & 9 & $\mathrm{Y}$ & $\mathrm{N}$ & $\mathrm{N}$ & $\mathrm{N}$ & $\mathrm{N}$ \\
\hline 5 & Cedar & 45 & 9 & $\mathrm{Y}$ & $\mathrm{N}$ & $\mathrm{N}$ & $\mathrm{N}$ & $\mathrm{N}$ \\
\hline 6 & Cedar & 45 & 9 & $\mathrm{Y}$ & $\mathrm{N}$ & $\mathrm{N}$ & $\mathrm{N}$ & $\mathrm{N}$ \\
\hline 7 & Cedar & 45 & $131 / 2$ & $\mathrm{Y}$ & $\mathrm{Y}$ & $\mathrm{Y}$ & $\mathrm{N}$ & $\mathrm{N}$ \\
\hline 8 & Cedar & 45 & $13 \frac{1}{2}$ & $\mathrm{Y}$ & $\mathrm{Y}$ & $\mathrm{Y}$ & $\mathrm{N}$ & $\mathrm{N}$ \\
\hline 4 & Cedar & 0 & $\begin{array}{c}18,13 \frac{1}{2} \\
9\end{array}$ & $\mathrm{Y}$ & $\mathrm{N}$ & $\mathrm{N}$ & $\mathrm{N}$ & $\mathrm{N}$ \\
\hline 2 & Cedar & 0 & 9 & $\mathrm{~N}$ & $\mathrm{~N}$ & $\mathrm{~N}$ & $\mathrm{~N}$ & $\mathrm{~N}$ \\
\hline 3 & Cedar & 0 & 9 & $\mathrm{Y}$ & $\mathrm{N}$ & $\mathrm{N}$ & $\mathrm{N}$ & $\mathrm{N}$ \\
\hline 9 & Cedar & 0 & $13 \frac{1}{2}$ & $\mathrm{Y}$ & $\mathrm{Y}$ & $Y$ & $Y$ & $Y$ \\
\hline 14 & Cedar & 0 & $13 \frac{1}{2}$ & $\mathrm{Y}$ & $\bar{Y}$ & $\mathrm{Y}$ & $\mathrm{N}$ & $\mathrm{N}$ \\
\hline 15 & Cedar & 0 & $131 / 2$ & $\mathrm{Y}$ & $\mathrm{Y}$ & $\mathrm{Y}$ & $\mathrm{N}$ & $\mathrm{Y}$ \\
\hline 13 & $\begin{array}{c}\text { Cedar/Pr } \\
\text { es. }\end{array}$ & 0 & $13 \frac{1}{2}$ & $\mathrm{Y}$ & $\bar{Y}$ & $\bar{Y}$ & $\mathrm{Y}$ & $\mathrm{N}$ \\
\hline 11 & Redwood & 0 & $13 \frac{1}{2}$ & $\mathrm{Y}$ & $\mathrm{Y}$ & $\mathrm{Y}$ & $\mathrm{Y}$ & $\mathrm{Y}$ \\
\hline 12 & $\begin{array}{c}\text { Redwood } \\
\text { / Pres. }\end{array}$ & 0 & $131 / 2$ & $\mathrm{Y}$ & $\bar{Y}$ & $\mathrm{~N}$ & $\mathrm{~N}$ & $\mathrm{Y}$ \\
\hline 16 & Vinyl & 0 & $131 / 2$ & Y & $\mathrm{N}$ & $\mathrm{N}$ & $\mathrm{N}$ & $\mathrm{N}$ \\
\hline 10 & Cedar & 0 & 18 & $Y$ & $\mathrm{Y}$ & $\mathrm{Y}$ & & $\mathrm{Y}$ \\
\hline
\end{tabular}




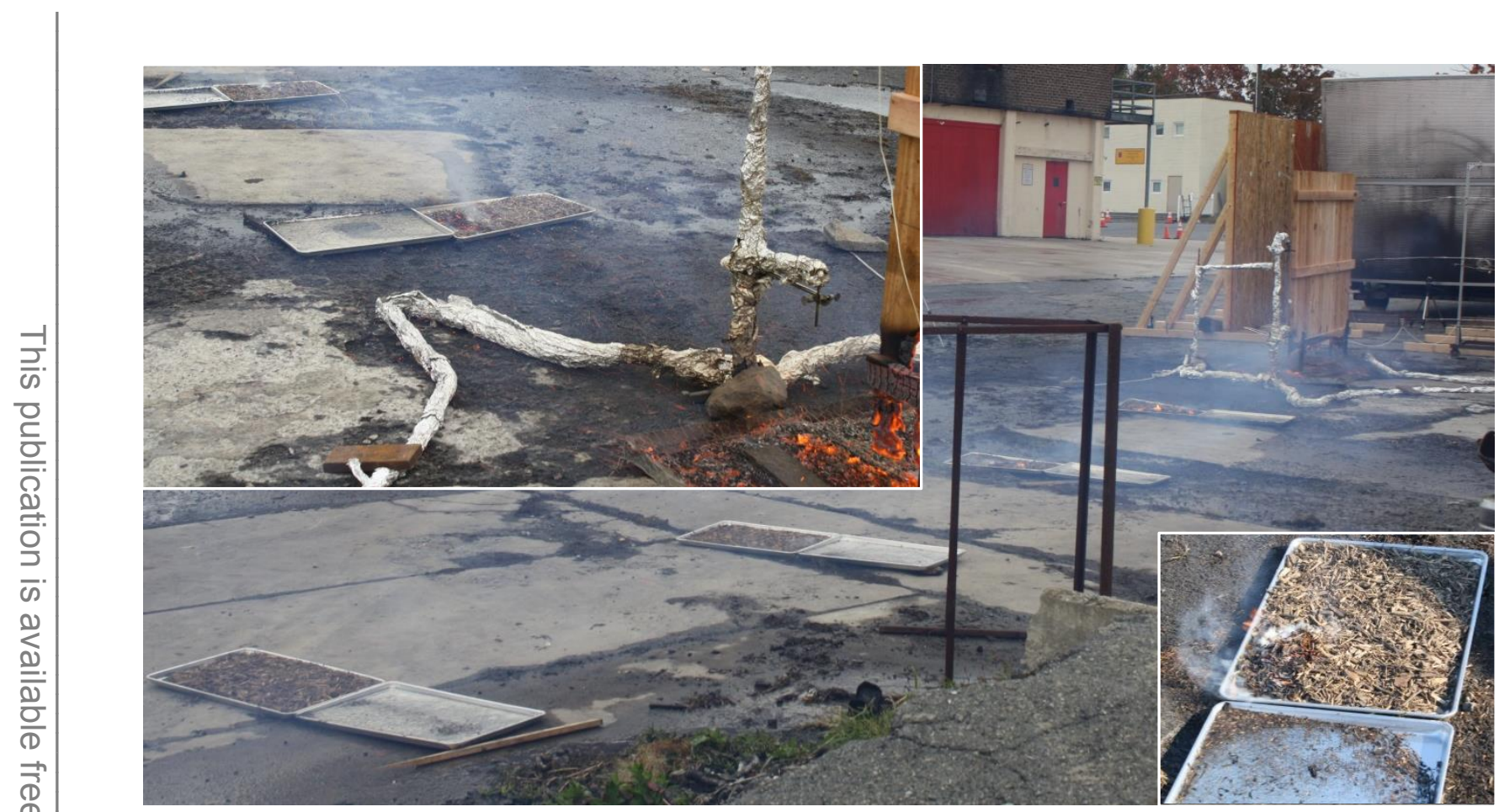

Figure 15 Photographs from Test 9 (cedar at $0^{\circ}, 13.5 \mathrm{~m} / \mathrm{s}$ ) showing three perspectives on the first $(3.05 \mathrm{~m})$ target pan with burning mulch and airborne firebrands.

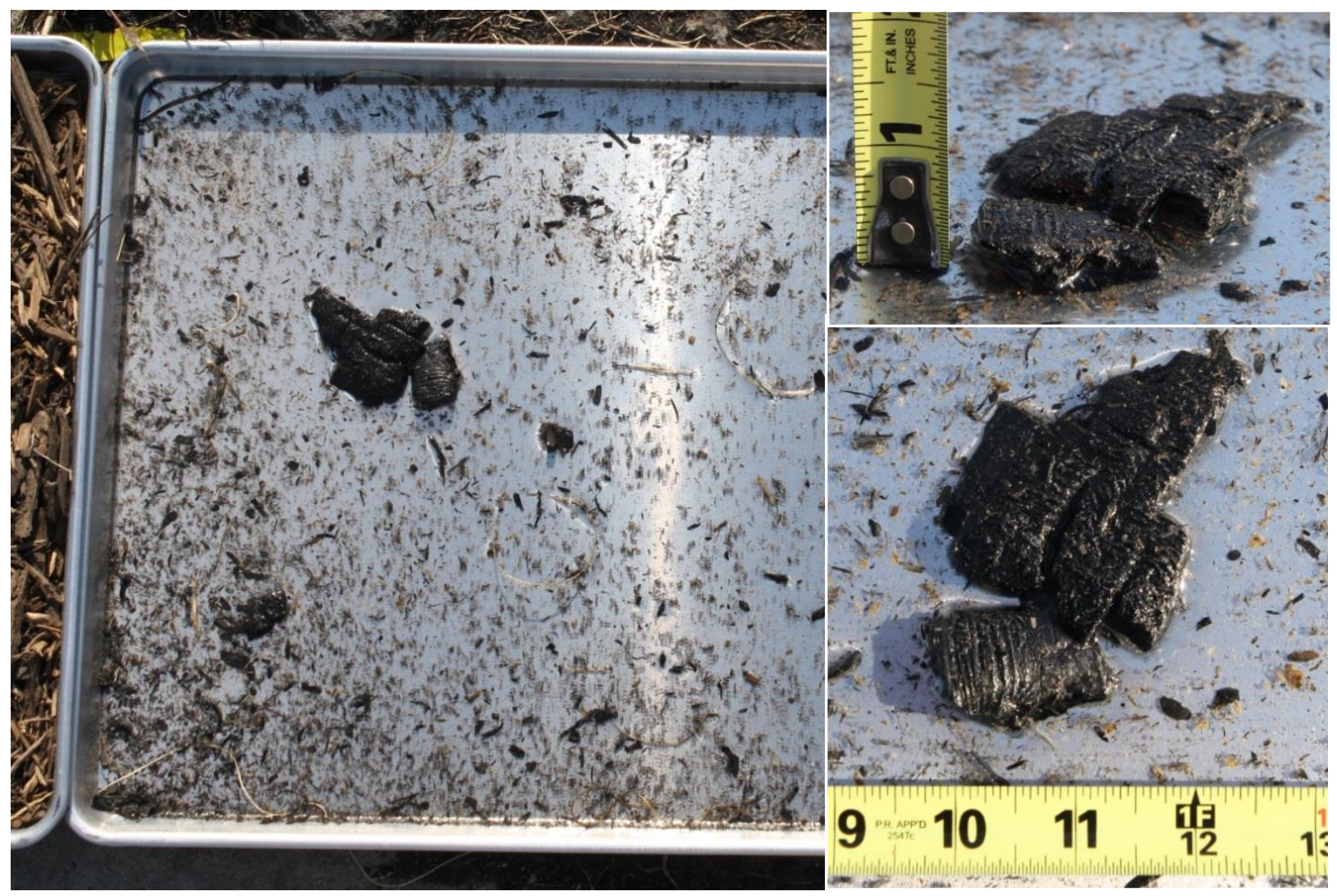

Figure 16 A photograph of a fence-generated firebrand in the first $(3.05 \mathrm{~m}$ from fence) water pan surrounded by smaller mulch-generated firebrands produced during Test 12 (preservative-coated redwood at $0^{\circ}, 13.5 \mathrm{~m} / \mathrm{s}$ ). Additional photographs provide size reference for the firebrand. 


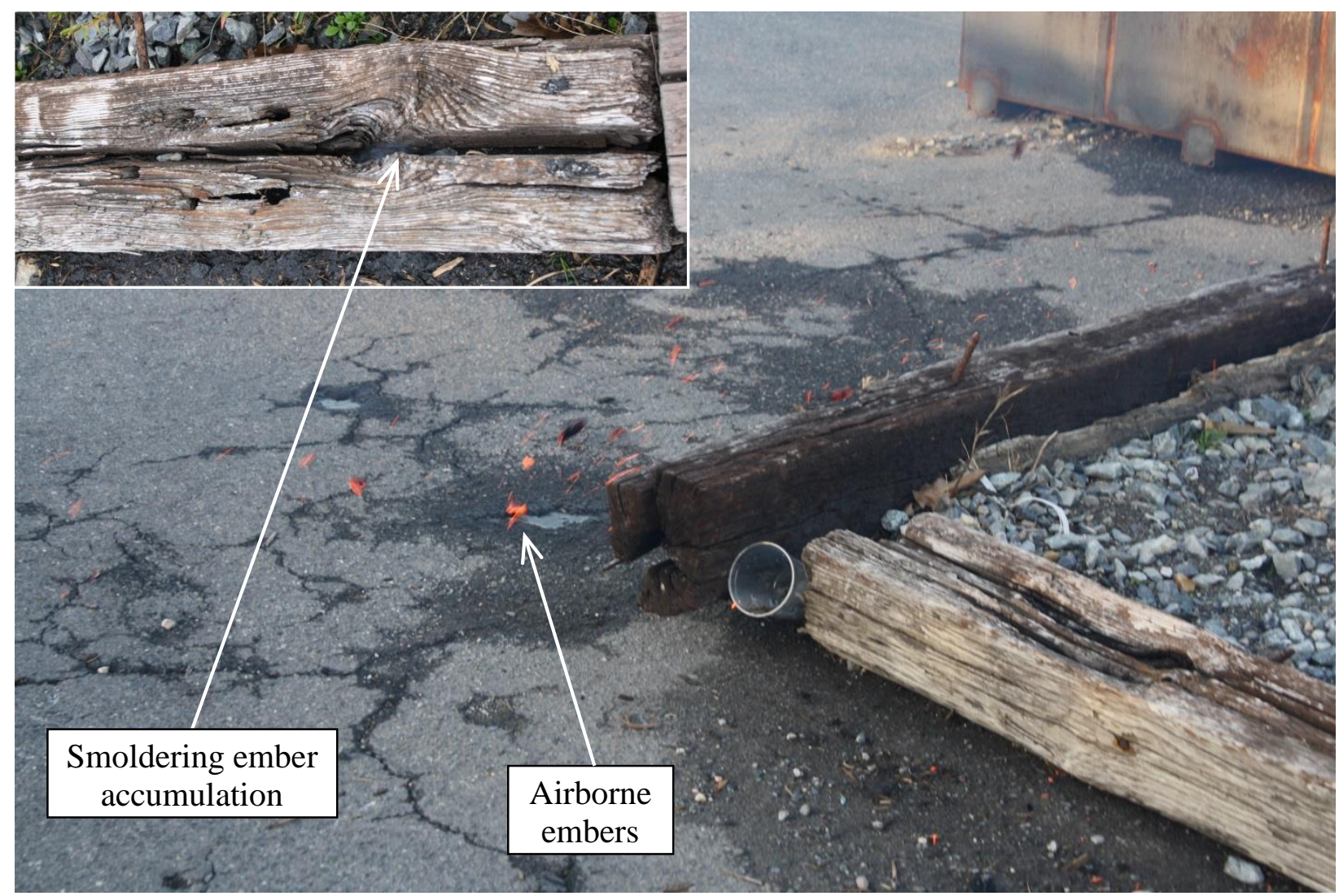

Figure $17 \mathrm{~A}$ photograph of a weathered and cracked railroad tie type of timber located over $18 \mathrm{~m}$ from the fence (upper left). During Test 10 (cedar at $0^{\circ}, 18 \mathrm{~m} / \mathrm{s}$ ), the timber was ignited in at least two locations where firebrands accumulated in cracks. The other photograph (bottom right) shows firebrands flying near the other end of the timber. 


\section{SUMMARY}

Experiments were conducted to examine the behavior of fire spread along privacy fences relative to wind speed and angle. Western redcedar was the primary fence material, but comparisons with California redwood and vinyl were made. Some experiments also focused on the effect of combustible mulch under the fence and the use of a preservative coating on the wood. It was determined that fire could spread horizontally along privacy fences as fast as $1.44 \mathrm{~m} / \mathrm{min}$, and the fastest rate occurred with winds in line with the fence. At that angle most conducive to flame spread, moderately high winds $(\approx 13.5 \mathrm{~m} / \mathrm{s})$ produced the fastest spread rate, while higher winds $(\approx 18 \mathrm{~m} / \mathrm{s}$ ) caused complex competition between sustained spread and extinguishment. The presence of a combustible ground cover beneath the fence was significant; in these experiments, fire did not spread without mulch. No significant differences in fire spread rate were found between cedar and redwood fence fires, and the use of wood preservative on the fence only caused qualitative burning behavior differences. The vinyl fence fire differed substantially from the wood fence fires due to differences in the fence structure and melting behavior of the vinyl when heated. Downwind mulch targets were found to be susceptible to ignition by fence firebrands, and smoldering ignitions were caused $18 \mathrm{~m}$ distant from the fence. An airboat propeller was found to produce a wind field which was uniform horizontally and vertically within $2.5 \mathrm{~m} / \mathrm{s}$ for conducting future wind-driven WUI fire experiments.

\section{FUTURE WORK}

Much more research is needed to determine the vulnerabilities of structures to fence fires relative to fence types and materials, the proximity and connection of the fence to the structure, and the design and exterior materials of the structure itself. Once the vulnerabilities are understood better, mitigation techniques such as material treatments and coatings can be explored beyond the simple solutions of increased separation and replacement of materials with non-combustible options. Initially, additional fence fire spread studies are planned which will examine more fence types and possible spread to attached or nearby structures. These experiments will generate different wind flow patterns than seen with straight sections of fence alone. Thermal measurements will be made nearer to the ground along the fence as well as on the attached or adjacent structures. The bi-directional probe array for velocity measurements will be improved with more rigidly supported ends to limit probe oscillations. After fences, further investigations of other peripheral home structures such as wood piles, landscape timbers, creosote-treated timber, and landscape plantings will be conducted. Together, these studies will inform existing and new codes and standards with quantitative fire spread mitigation and structure protection strategies based on experimental data.

\section{ACKNOWLEDGEMENTS}

The authors thank Montgomery County Fire and Rescue Training Academy for providing space and physical support for the experiments, Sandy Spring Volunteer Fire Department for their airboat, Chief George Brown for running the airboat, Marco Fernandez of NIST for putting together and helping run these large experiments, and the NIST National Fire Research Laboratory (NFRL) staff (Laurean DeLauter, Tony Chakalis, Brian Story, Doris Rinehart, Artur Chernovsky, Matthew Bundy) for fabrication and experimental assistance. 


\section{REFERENCES}

[1] A. Maranghides and W. E. Mell, A Case Study of a Community Affected by the Witch and Guejito Fires, NIST TN 1635, 2009.

[2] A. Maranghides, D. McNamara, C. Leland, R. Vihnanek, J. Restaino, A Case Study of a Community Affected by the Waldo Fire - Event Timeline and Defensive Actions. NIST TN Report in Progress, 2015.

[3] R. Gorte, The Rising Cost of Wildfire Protection. Headwaters Economics (available online at http://headwaterseconomics.org/wphw/wp-content/uploads/fire-costs-background-report.pdf), 2013.

[4] M. J. Gollner, R. Hakes, S. Caton, K. Kohler, Pathways for Building Fire Spread at the Wildland Urban Interface. The NFPA Fire Protection Research Foundation Final Report, 2013.

[5] A. Maranghides, W. E. Mell, K. Ridenour, D. McNamara, Initial Reconnaissance of the 2011 Wildland-Urban Interface Fires in Amarillo, Texas, NIST TN 1708, 2011.

[6] S. L. Manzello and S. Suzuki, Experimentally Simulating Wind Driven Firebrand Showers in Wildland-urban Interface (WUI) Fires: Overview of the NIST Firebrand Generator (NIST Dragon) Technology Procedia Engineering, 62, 2013, pp. 91-102.

[7] S. L. Manzello, S. H. Park, J. R. Shields, Y. Hayashi, S. Suzuki, Comparison Testing Protocol for Firebrand Penetration Through Building Vents: Summary of BRI/NIST Full Scale and NIST Reduced Scale Results, NIST TN 1659, 2010.

[8] S. L. Manzello, Y. Hayashi, Y. Yoneki, Y. Yamamoto, Quantifying the vulnerabilities of ceramic tile roofing assemblies to ignition during a firebrand attack. Fire Safety Journal 45, 2010, pp. 35-43.

[9] S. L. Manzello, S. Suzuki, Y. Hayashi, Exposing Siding Treatments, Walls Fitted with Eaves, and Glazing Assemblies to Firebrand Showers. Fire Safety Journal 50, 2012, pp. 25-34.

[10] S. L. Manzello and S. Suzuki, Exposing Decking Assemblies to Continuous Wind-Driven Firebrand Showers, in: P. van Hees, R. Jansson, and D. Nilsson (Eds.) Fire Safety ScienceProceedings of the Eleventh International Symposium on Fire Safety Science, vol 11, IAFSS, 2014.

[11] S. Suzuki, E. L. Johnsson, A. Maranghides, \& S. L. Manzello, Ignition of Wood Fencing Assemblies Exposed to Continuous Wind-Driven Firebrand Showers. Fire Technology, 1-17, 2015.

[12] J. E. Leonard, R. Blanchi, N. White, A. Bicknell, A. Sargeant, F. Reisen, M. Cheng, K. Honavar, Research and investigation into the performance of residential boundary fencing systems in bushfires, CMIT-2006-186, 2006.

[13] A. M. Grishin, A. I. Filkov, E. L. Loboda, V. V. Reyno, A. V. Kozlov, V. T. Kuznetsov, D. P. Kasymov, S. M. Andreyuk, A. I. Ivanov, N. D. Stolyarchuk, A field experiment on grass fire effects on wooden constructions and peat layer ignition. International Journal of Wildland Fire, 23(2), 2014, pp. 445-449.

[14] W. E. Mell, S. L. Manzello, A. Maranghides, D. Butry, R. G. Rehm, The wildland-urban interface fire problem - current approaches and research needs. International Journal of Wildland Fire, 19, 2010, pp. 238-251.

[15] J. L. Pellegrino, N. P. Bryner, E. L. Johnsson, Wildland-Urban Interface Fire Research Needs- Workshop Summary Report, NIST SP 1150, 2013.

[16] W. T. Simpson, Equilibrium moisture content of wood in outdoor locations in the United States and worldwide. Research Note FPL-RN-0268, U.S. Forest Products Laboratory. 1998. 